\title{
Endogenous Institutional Change After Independence
}

Working Papers in Economics No 163

(This version: March, 2005)

\author{
Heather Congdon Fors and Ola Olsson \\ Department of Economics \\ Göteborg University \\ Box 640, Vasagatan 1, 40530 Göteborg \\ SWEDEN \\ Email: heather.congdon@economics.gu.se
}




\title{
Endogenous Institutional Change After Independence
}

\author{
Heather Congdon Fors and Ola Olsson* \\ Department of Economics \\ Göteborg University \\ email: heather.congdon@economics.gu.se
}

\begin{abstract}
A key event in economic history was the independence of nearly ninety former colonies after World War II. On the basis of qualitative and quantitative evidence, we argue that independence often constituted an institutional disequilibrium that the new regimes reacted to in very different ways. We present a model of endogenous changes in property rights institutions where an autocratic post-colonial ruler faces a basic trade-off between stronger property rights, which increases his dividends from the modern sector, and weaker property rights that increases his ability to appropriate resource rents. The model predicts that revenuemaximizing regimes in control of an abundance of resource rents and with insignificant interests in the modern sector will rationally install weak institutions of private property, a prediction which we argue is well in line with actual developments in for instance DR Congo, Ghana, and Zambia.
\end{abstract}

Keywords: institutions, property rights, independence, resource rents, rent seeking

JEL Codes: O17, O57, P14

\section{Introduction}

The rules that societies live by have proven to be crucial for all kinds of economic development. A number of recent studies have established links between the general quality of countries' institutions and for instance income per capita (Hall and Jones, 1999; Acemoglu, Johnson and Robinson (AJR), 2001a, 2002; Easterly and Levine, 2003; Acemoglu and Johnson, 2003; Olsson and Hibbs, 2005). Perhaps more difficult to understand is what explains the wide international variation in measures of institutional quality. Empirical

\footnotetext{
${ }^{*}$ We are grateful for comments from Arne Bigsten, Anke Hoeffler, Johanna Jussila, Kalle Moene, Violeta Piculescu, and from the participants of seminars at Göteborg University, the Nordic Workshop in Development Economics, and the CSAE Conference at Oxford University. Olsson gratefully acknowledges financial support from the Malmsten Foundation.
} 
and theoretical efforts in this tradition have typically focused on deep historical explanations such as the various effects of colonialism (AJR, 2001a, 2002; Sokoloff and Engerman, 2000) or the role of the sovereign in the legal and economic systems of medieval Spain, France, and Britain (North, 1990; Glaeser and Shleifer, 2002). However, although institutions typically display a high degree of persistence, we believe that the institutional configuration of countries is undoubtedly also influenced by more recent historical events. One such crucial event was the almost simultaneous independence of around 90 former colonies of varying size after World War II.

In this article, we consider the development of property rights institutions and constraints against the executive in former colonies from independence to the present day. We take 'as given' the possible deeper effects of geography and the identity of the colonizer, and model endogenous institutional choice for a more or less autocratic ruler who maximizes his own utility in a twoperiod setting. The first period starts at independence and is typically characterized by an 'institutional disequilibrium' for the new regime. The ruler has economic interests in a modern, formal sector but can also appropriate rents from a state-controlled natural resource sector. These circumstances imply that the ruler faces a basic trade-off between weak and strong institutions of private property. Strong property rights will make the formal sector prosper and raise the ruler's incomes from that sector. Weaker property rights, on the other hand, means a poorly functioning formal economy but makes the ruler's expropriation of rents easier.

Our model predicts that rulers are more inclined to weaken property rights if easily appropriable natural resource rents abound, whereas the lack of an 'easy rents-sector' coupled with substantial interests in a modern sector will motivate even an autocratic ruler to install stronger private property rights, which in turn results in higher growth. The costs of institutional change also play a central role in our model. Such costs will to a great extent depend on the geography of the country, in particular on the geographical distribution of the population and on the country size. In addition, a higher initial level of property rights protection will diminish, in some instances even negate, the negative impact of natural resource abundance on growth, as demonstrated empirically by Mehlum et al (2002). ${ }^{1}$

We argue that the main insight from our model is well in line with observed

\footnotetext{
${ }^{1}$ See Sachs and Warner (2001) and Woolcock et al (2001) for discussions of the possible reasons for the observed 'curse of natural resources'.
} 
experiences in several developing countries after independence. Singapore and Democratic Republic of the Congo - both ruled by autocratic regimes but found at the opposite ends of the scale in measures of property rights protection - might serve as illustrations. In Singapore, the absence of an easy rents-sector and the ruling elite's strong interests in the modern sector implied that a maintenance and strengthening of property rights was a natural strategy for the government. This institutional policy was further facilitated by the small size of the country and a relatively homogeneous society. In DR Congo, on the other hand, natural resource rents had been significant all through the colonial era whereas the clique around the military commander Mobutu, who seized power soon after independence, had virtually no interests in a modern sector. This fact, together with an extremely complicated geography for the broadcasting of power (Herbst, 2000), implied that property rights institutions deteriorated even further after independence.

On a more general level, we show in Figure 1 that a commonly used measure of the strength of Rule of law from Kaufmann et al (2003), capturing aspects like the strength of property rights institutions, is strongly negatively associated with country size in a regression for 49 countries that were decolonized after 1945. The figure shows the correlation that remains after controlling for the impact of colonial institutions (proxied by AJR's (2001) measure of settler mortality). We believe that country size picks up the effects of a number of mediating factors that are key ingredients of our model, for instance that size is positively related to the prevalence of valuable point resources such as minerals, that large countries are more likely to be run by elites with no interests of their own in a modern sector, and that the costs of institutional change are higher in large countries. ${ }^{2}$ Since size of country presumably has played a larger role for the countries in question after independence, we believe Figure 1 also points to the importance of post-colonial institutional change.

Our research extends a long tradition stretching back to Adam Smith that emphasizes the central role of property rights in development (Coase, 1960; Demsetz, 1967; Alchian and Demsetz, 1973; North, 1981, 1990; FirminSellers, 1995; de Soto, 2000). Like North (1981), Acemoglu and Johnson (2003), and Djankov et al (2003), we recognize that property rights institutions affect the economy along two dimensions. The first dimension is the

\footnotetext{
${ }^{2}$ See Alesina and Spolaore (1997) for a formal model of the optimal size of countries and Alesina (2003) for a general discussion of the impact of country size on national economies.
} 
relationship between common men, for instance whether private property is secure against expropriation by a neighbor. The second dimension is the interaction between ruler and subject and to what extent the ruler can expropriate means from his people. In their empirical efforts to 'unbundle' institutions to determine what kind of influence that different institutions have, Acemoglu and Johnson (2003) show that property rights constraining the ruler from expropriation appears to be the more important dimension for development. Djankov et al (2003) suggest that countries face an 'institutional possibility curve' (IPC) with a basic trade-off between disorder with a weak state and private solutions, and dictatorship with a strong state. In their empirical analysis, Glaeser et al (2004) show that almost all countries that were poor in 1960 were dictatorships. The crucial question that arises from their analysis, and which we examine in this article, is why some autocratic rulers pursued growth-oriented policies (such as strengthening property rights institutions) while others did not.

Besley (1995) proposes several models for the relationship between property rights and capital investment in a micro-level analysis of property rights in two regions in Ghana. Though highly relevant at the micro level, these models have little to say about the considerations at the macro level of a utility maximizing autocrat. Like us, Svensson (1998) analyzes the potential reasons why a government does not invest in stronger property rights. The basic reason in Svensson's model is that rulers are uncertain about staying in power due to political instability and hence do not internalize the full benefit if institutional investment, a scenario which differs from ours where the potential for capturing rents is the key feature. Persson (2004) argues that the emergence of parliamentary democracy might be an important mediating factor between historical institutions on the one hand and 'structural policies' (what is referred to here as institutions) and economic performance on the other. In our model, we take a low degree of democracy as given, an assumption which seems to be well in line with the evidence in Glaeser et al (2004). Other models of property rights and growth include Tornell (1997) and Sonin (2003).

We believe that former colonies that were decolonized after 1945 are worthy of a separate modelling effort like that presented below for several reasons. Firstly, long-run universal theories arguing that colonial institutions emerged as a rational response to the prevailing disease environment or to population density (AJR, 2001, 2002a) have a problem in their treatment of the American 
colonial era (1500-1825 AD) and the African era (1885-1965) as one historical process. Indeed, for various reasons, AJR's (2001) settler mortality-variable has turned out to have a poor explanatory power for understanding the crosscountry variation in African institutions (Olsson, 2004a). Thus, we will focus here on the experience of the roughly 90 countries that received independence after 1945 .

Secondly, former colonies are overrepresented among the countries with the weakest property rights institutions in the world today. ${ }^{3}$ Thirdly, the installment of enforceable property rights in Africa faces extraordinary challenges due to low population density and an adverse geography (Herbst, 2000; Sachs, 2001), as well as the greatest ethnical diversity in the world (Easterly and Levine, 1997; Alesina et al, 2003). Fourth, due to the massive inflows of humanitarian aid, Africa's strategic role in the Cold War, and the great abundance of natural resources, Africa has been extremely well endowed with easily appropriable rents that have exerted a strong influence on kleptocratic rulers and potential rebels (Collier and Hoeffler, 1998; Acemoglu, Robinson, and Verdier, 2003; Olsson and Congdon Fors, 2004).

The paper is organized as follows. Section two develops the basic argument by analyzing post-colonial experiences of institutional development. Section three outlines the ruler's basic trade-off in terms of investment in property rights institutions and proceeds by presenting a solution to the full model. Section four then makes labor supply endogenous and introduces variations such as trade liberalization. Section five concludes the paper.

\section{Institutional Development After Independence}

\subsection{Macro level}

Independence from colonial rule meant the onset of a new era that was often accompanied by discontinuous changes in policy. Some countries soon emerged as stable states with well functioning market institutions whereas others saw a continuation of the extractive policies from colonial times and others still a deterioration from a relatively favorable initial position. As an example of the first type of country, Singapore (independent in 1965) rapidly developed an impressive export sector and strong institutions for private prop-

\footnotetext{
${ }^{3}$ Kauffman et al's (2003) indicator 'Rule of law', which is measured for more than 190 countries, suggests that in the year 2002, 13 of the 20 lowest-scoring countries were African. See also the Data Appendix for the scores of 88 former colonies.
} 
erty. DR Congo, on the other hand - badly misgoverned by Belgian colonists - received independence in 1960 and immediately continued on the track of private property violations, corruption, and social conflict. Lastly, Ghana which was one of the first countries to become independent in 1957 and believed to have a bright future - soon followed many other African countries in adopting inward-looking policies and central planning of key sectors. After long periods of military rule and social disorder, Ghana emerged as a typical poor African country.

It has been claimed by several researchers that widely different experiences like these can be attributed to the institutions created by the colonial regimes before independence (AJR, 2001a, 2002; Acemoglu et al, 2003; Easterly and Levine, 2003). In places where conditions where unfavorable for white settlements and where there were plenty of easily lootable wealth, the colonial powers installed 'extractive' institutions with weak private property rights whereas in places where the opposite conditions prevailed, white settlers moved in and set up 'neo-European' colonial states. As an instrumental variable for measuring the quality of current and past institutions, AJR (2001a) introduced a measure of settler mortality during colonial times that explained a great part of the variation in institutional quality in the 65 former colonies in their sample. ${ }^{4}$

The argument that we make is that although colonial policy certainly is relevant for understanding the current institutional environment, independence was something of a crossroads that took countries in widely different directions. The empirical record gives an indication of this. In Appendix 1, we present data on the strength of property rights institutions for 88 colonies that were colonized after World War II. The data was originally collected by the World Bank and the Rule of law-variable is one of six indicators on the quality of government in the world. Rule of law captures aspects like the strength of property rights and the risk of government expropriation and is thus most suitable for our purposes. ${ }^{5}$ The average score in our sample is 4.27 - to be compared with 5 for the whole world - and the standard deviation is 1.55 , suggesting a rather substantial variation.

If we regard AJR's (2001) Settler mortality-variable as a proxy for historical institutions and run a regression for Rule of law for 49 countries, we

\footnotetext{
${ }^{4}$ See Albouy (2004) and Olsson (2004a) for a more detailed discussion of the validity of these results.

${ }^{5}$ See Kaufmann et al (2003) for a description of the data. The Rule of law-variable is normalized to range between 0 and 10 .
} 
receive a negative and significant estimate as predicted with an $R^{2}$ at 0.23 . However, in order to account for the rest of the variation in institutional quality, the use of Area of the country as an independent variable provides some suggestive results. ${ }^{6}$ For reasons outlined in some detail in the remainder of the article, we propose that large former colonies were more likely to experience a worsening or property rights institutions after independence than smaller countries.

There are three basic reasons for this hypothesis: Larger countries are more likely to be endowed with valuable 'point' resources like minerals and oil that easily become targets in rent seeking contests (Acemoglu, Robinson, and Verdier, 2003; Olsson and Congdon Fors, 2004). Secondly, the costs of changing or enforcing property rights institutions increase with geographical distance from the capital (Herbst, 2000). Thirdly, larger countries are more likely to host a variety of social groupings and the government is more often controlled by a particular group that might not be interested in the welfare of society at large (Bates, 1981; Easterly and Levine, 1997; Alesina, 2003). ${ }^{7}$

Figure 1 shows on the vertical axis the unexplained part of the variation from a regression of Rule of law on Settler mortality for 49 countries that were decolonized after 1945. Country size in log form is shown on the horizontal axis. In line with the reasoning above, there is a clear negative relationship. Although we would certainly not like to draw any firm conclusions from these statistical correlations, we believe that Figure 1 is conducive to a view arguing that both colonial institutions (proxied by settler mortality) and post-colonial policy are relevant for understanding institutional quality today. In order to make our hypothesis more concrete, we will briefly discuss the post-independence development in five countries; Singapore, DR Congo, Botswana, Zambia, and Ghana.

\subsection{Country examples}

Singapore achieved full independence from Great Britain in 1965, but the first steps towards independence began ten years earlier with the proclamation of Singapore's first constitution and the first parliamentary elections. By 1959

\footnotetext{
${ }^{6} \mathrm{~A}$ casual glance in the Data Appendix immediately shows that small countries like Singapore, Barbados, and Hong Kong are overrepresented among the top scorers for Rule of law.

${ }^{7} \mathrm{~A}$ pure test our this hypothesis would seek to establish a causal relationship from size of the country to point resource rents, costs of property rights reforms, and social heterogeneity, and then from these factors to the strength of property rights institutions. However, such a formal test is beyond the scope of this theoretical article.
} 
a Singaporean, Lee Kwan Yew, had replaced the British governor as head of state, giving Singapore autonomy over its internal affairs (Haas, 1999). This relatively smooth transition from colony to independent country meant that Singapore not only had a comparatively developed and prosperous economy, but also well-functioning institutions (Huff, 1999).

Singapore's geography presented both challenges and opportunities. On the one hand, Singapore is not directly connected to a self-supporting agricultural base and relies on neighboring Malaysia for its water supply, leaving the country somewhat vulnerable. On the other hand, the lack of natural resources and agriculture made export-led economic growth a natural goal for the new leaders of Singapore. Further, the city-state does not exhibit large ethnic fractionalization, and the its compact size reduces the costs of the broadcasting of power.

From the outset, Singapore aimed to attract foreign investment, and in 1978 several new laws were introduced to attract foreign business, such as the abolition of capital flows restrictions and capital gains taxes. As a result, foreign direct investment in Singapore rose dramatically (Huff, 1999). The government is also involved in the economy, operating a large number of statutory boards (approximately 70) and government linked corporations (approximately 500) (Lingle and Wickman, 1999). One reason for such government involvement in the private sector is that the government can provide investment capital when it deems that the market is being overcautious ( $\mathrm{Li}$, 2002).

Singapore's economic success relies on several factors. Good initial institutions play a large role, as do geographical factors such as size and the existence of a large natural port. The government's willingness to commit to strong economic policies is also critical, and helped in part by the stability of the ruling People's Action Party, which has held at least 95 percent of the seats in parliament since 1968. Finally, by focusing on multinational corporations, Singapore has facilitated the transfer of technology to its economy, a problem that other developing countries have had troubles overcoming (Lingle and Wickman, 1999).

While Singapore is an example of economic success in a former colony, DR Congo is an example of one of the worst economic failures. DR Congo's transition to independence did not run smoothly; Belgium shortened the time horizon from four years to six months after witnessing the problems France had with its own decoloninzation project (Saideman, 1997). In addition, the 
Belgian colonial rulers had focused most of their efforts on the extraction of mineral resources and did not leave DR Congo with a strong institutional framework.

DR Congo's geography has proven to be problematic as well. The country is vast, but the population is concentrated to areas around the borders, while the interior is virtually empty. This makes investment in both infrastructure and institutions costly and relatively inefficient (Herbst, 2000). The high degree of ethnic fractionalization in DR Congo only serves to exacerbate the problem. Even DR Congo's immense wealth of natural resources have had a disastrous effect on the country's economic growth.

Mobutu Sese Seko took power in DR Congo in 1965 and had started a process called 'Zairianization' by the 1970s, which involved the transfer of most of the colonial enterprises and a considerable portion of the agricultural sector to the government (Young, 1994). As the economy continued to falter, Mobutu focused his efforts increasingly on personal enrichment. By far the most rewarding enrichment strategy was Mobutu's control of the natural resource sector, primarily through the state-owned mining company. Further, Mobutu received extensive foreign aid from his western allies due to DR Congo's role as an anti-communist bastion in Africa. Mobutu's private fortune is believed to have been as much as 4 billion USD in 1984, an amount almost equivalent to the country's foreign debt at the time. In the meantime, DR Congo was plagued by poor economic growth and a mounting public external debt. Mobutu was finally overthrown in 1997 by a rebel group led by Laurent Kabila, who took over as president of DR Congo and quickly began to emulate the practices of the deposed Mobutu (Nzongola-Ntalaja, 2002).

In stark contrast to Singapore, DR Congo was faced with several disadvantages at the time of independence. The initial quality of institutions was quite low, and the transition from colony to independent country was not a smooth one. Further, the size of geographic size of DR Congo was not conducive to institutional investment. The availability of vast amounts of natural resource rents provided Mobutu, and later Kabila, with little incentive to expand the formal economy. Although Kabila's son, Joseph, has shown signs of moving away from the legacy of kleptocracy, the continued conflict in and around the country reduces both Kabila's ability to improve institutions and the attractiveness of DR Congo to foreign investment.

If DR Congo is perhaps the worst of all African tragedies, Botswana is one of the success stories. The country was a British colony (Bechuanaland) 
and received independence in 1966. Although the land area is relatively large, most of the country is uninhabited desert and almost all of the population lives in the south-east. According to the criteria developed by Herbst (2000), the geographical distribution of Botswana's population is therefore relatively favorable with low costs for the broadcasting of power.

Upon independence, the country was believed to have a bleak future due to the lack of industries and agricultural potential. However, according to Acemoglu et al (2001b), social institutions actually started off from a relatively good level. Colonial policy had in most instances left few marks on the country and the parliament-like democracy practiced within the dominant Tswana tribe (in an assembly referred to as the kgotla) continued to play a central role after independence which meant that the ruling elite was more effectively constrained than elsewhere. Another favorable circumstance was that the Tswana elite that gained power after independence had themselves important stakes in the only significant export-sector for cattle. This may have further strengthened incentives to maintain strong private property rights.

The discovery of enormous diamond reserves of high quality around 1970 then transformed the Botswanan economy. Unlike in countries with less favorable initial institutions and distributions of power, the large rents from the mineral sector were used for investments in public goods like education and infrastructure, and also in the strengthening of property rights and law and order (Acemoglu et a, 2001b). As discussed in Olsson (2004b), the joint venture between the Botswanan state and the South African diamond firm De Beers presumably also served as a disciplining device in this regard. By 2005, the country has standards of living comparable to most upper-middle income countries in the world.

Post-independence developments were almost quite the opposite in Botswana's neighbor Zambia. During the colonial era, the territory was known as Northern Rhodesia and was administered first by the South Africa Company and then by the UK. The abundance of copper reserves was well known already in the early 1900s and contributed to the rapid industrialization and urbanization of the mining areas in the 1920s and 1930s. The colony also hosted a large white settler population. At independence in 1965, Zambia was one of the most industrialized and prosperous countries in Sub-Saharan Africa.

Zambia's subsequent economic decline and institutional reversal is almost as dramatic as Botswana's rapid development. Both countries started off 
with reasonably favorable institutions after British colonial rule. But whereas Botswana's post-independence elite had important interests in the existing export sector, the Zambian government during the 'First Republic' (1965-1973) had not. As argued by Collier and Bates (1993), Zambia was distinguished by the circumstance that the independent government - led by the United National Independence Party (UNIP) - was more or less completely alienated from the progressive sectors in society such as manufacturing and commercial agriculture.

The party's core constituency was instead urban mining workers and the state's major source of revenue was the state mining conglomerate Zambia Industrial and Mining Corporation (ZIMCO). The UNIP government had nationalized the copper industry in 1969. In order to gain ground also within the modern sector, the government created state enterprises in manufacturing that received subsidies and tax credits and that undermined the operation of many private firms. The reduction of competition in the business sectors was soon accompanied by the initiation of one-party rule in 1972 with UNIP in power. When copper prices then fell in the middle of the 1970s, Zambia was caught in a vicious circle of economic deterioration which was met by further distortionary interventions by the government (Collier and Bates, 1993).

Even though liberalization efforts were made in the 1980s and 1990s, the basic pattern prevailed with a government that was dependent on rents from a poorly functioning mineral sector and that neglected the modern sectors. As documented by Bigsten (2001), rent seeking and various forms of corruption was widespread throughout the period. The major vehicle for rent extraction continued to be the state owned monopoly ZIMCO until it was finally privatized in 2000 .

Zambia's starting position was relatively similar to that of Ghana. First among African nations, Ghana received independence already in 1957 and was by then one of Africa's more advanced states politically as well as economically. However, like in Zambia, the government under Kwame Nkrumah soon started to adopt import-substituting policies, combined with an overvalued exchange rate and a nationalization of firms. The elite that came into power had few vested interests of their own in business or in commercial agriculture (Bates, 1981).

The country's main source of export apart from gold is cocoa production. Although an agricultural good like cocoa is not a point resource in the sense that a mine is, it has been shown that coffee and cocoa producing countries 
have had almost as poor economic development after independence as point resource countries (Woolcock et al, 2001). We believe that this can largely be explained by the use of 'marketing boards'. Marketing boards are statecontrolled monopsonies for the purchase of agricultural products from small farmers which are then sold on the world market. The existence of marketing boards was motivated by the fact that the world market prices of cocoa and coffee tend to fluctuate a lot. By keeping the price towards farmers stable, the marketing boards were intended to accumulate funds during booms which would then ensure farmers a higher price than on the world market in bad times.

Although this institution sounds reasonable in theory, it has been a major source of corruption and rent seeking in several African countries. As described extensively by Bates (1981), the existence at independence of large accumulated funds provided too great a temptation for revenue-hungry rulers with no vested interests of their own in the modern sectors. In Ghana, the marketing board for cocoa was gradually taken over by the state. This strategy was yet another step towards a more or less intentional weakening of property rights, and the response was a decline in cocoa production as well as in manufacturing. The country soon elapsed into serious political turmoil with military coups and dictatorial regimes.

We believe that the lesson from these country examples is that the prevalence of a government-controlled stream of resource rents, in combination with weak interests in the modern sectors as in DR Congo, Zambia, and Ghana, provided post-independence rulers with incentives to neglect or indeed weaken private property rights institutions. In the initially resource-poor Singapore and Botswana, a strengthening of property rights proved to be a more promising strategy for the revenue-seeking elites. When the windfall gains from diamond mining then fell on Botswana, the appropriate institutions were in place to use the rents for truly growth-promoting strategies.

\section{The Model}

In this section, we present a two-period model of an autocratic ruling elite's endogenous choice of costly property rights reforms. For simplicity, we assume that the ruler does not have to worry about being overthrown as long as he provides a minimum of public goods. ${ }^{8}$ The country has just emerged from

\footnotetext{
${ }^{8}$ There is a growing literature studying the mechanisms through which non-benevolent rulers might stay in power for decades in developing countries despite the presence of po-
} 
independence and the ruler has inherited property rights institutions from a former colonial regime. While it is possible that these institutions are optimal, it is more likely that they are not. As will be shown, the model serves to explain how it even might be optimal for a ruler to weaken property rights institutions.

\subsection{Basics}

Let us assume a scenario with an autocratic ruler or ruling elite who is primarily motivated by the possibility of making personal revenue with the least possible effort. The ruler has two potential sources of personal gain: his commercial interests in a modern private sector and a more or less easily appropriable flow of rents from a government-owned natural resource sector. These incomes are available in a current as well as in a future period. The ruler also controls (but cannot make personal gain of) the government budget with revenues from the natural resource sector and income taxes on labor. In order to avoid being overthrown, the ruler has to supply a fixed (minimum) amount of public goods like infrastructure, defense, and police in his first period to uphold the most fundamental functions of the state. What remains in the public budget can be spent on costly reforms of the prevailing property rights institutions. It is assumed that all changes in property rights, regardless of whether they involve a weakening or a strengthening or rights, give rise to direct costs. The ruler gains utility only from personal enrichment.

These basic assumptions are summarized in equation (1), showing the ruler's utility function in general form:

$$
U_{r}=R_{0}+M_{0}-e\left(\left|Z_{1}-Z_{0}\right|\right)+\delta\left[R_{1}\left(Z_{1}\right)+M_{1}\left(Z_{1}\right)\right]
$$

The utility of the ruler is a simple linear function of wealth in the form of current and future expropriated rents $R_{0}$ and $R_{1}\left(Z_{1}\right)$ and of current and future profits from the ruler's interests in the modern sector $M_{0}$ and $M_{1}\left(Z_{1}\right)$. Utility is also a negative function of the effort of changing property rights $e\left(\left|Z_{1}-Z_{0}\right|\right) . \delta \leq 1$ is a time discount factor. $Z_{1}$ is the quality of property rights institutions in the future period and is the ruler's key choice variable. He has inherited a property rights regime of strength $Z_{0}$ and considers increasing or decreasing this level. The personal costs of these changes are a function of the absolute level of $\left(Z_{1}-Z_{0}\right)=\Delta Z$ such that $e^{\prime}(|\Delta Z|)>0$ and $e(0)=0$. In other words, investments over the prevailing level $(\Delta Z>0)$ give tential rebels (Olsson and Congdon Fors, 2004; Acemoglu, Robinson, and Verdier, 2003) 
rise to an equally large disutility as disinvestments $(\Delta Z<0)$ and the least disutility is gained from status quo $(\Delta Z=0)$ when no effort at all is exerted in either direction.

A central assumption of the paper is that $R_{1}^{\prime}\left(Z_{1}\right)<0$ since stronger property rights make expropriation of rent for personal gain harder. Equivalently, $M_{1}^{\prime}\left(Z_{1}\right)>0$ since stronger property rights will have a positive effect on output in the modern sector. The assumption that the same type of property rights institutions affect the natural resource sector and the modern sector is a cornerstone of our model. A potential objection might be that the institutions constraining the ruler from expropriating natural resource rents are different from the institutions affecting modern sector output. If that was the case, there would be no trade-off of the kind modelled here and a kleptocratic ruler should simply minimize the constraints against expropriation in the natural resource sector and maximize the strength of private property rights in the modern sector. ${ }^{9}$

However, as will be specified below, it will be assumed here that the ruler's revenue from the modern sector comes from minority share-holding. Since the ruling elite thus is directly involved as owners both in the resource and the modern sector, rational firm-owners in the modern sector will judge the quality of property rights by the standards of behavior that the ruler employs in the resource sector. If the ruler expropriates natural resource rents at a great scale, they will expect that sooner or later he will do the same in the modern sector. Hence, both sectors will be affected by the same set of property rights institutions, measured by $Z_{t}$.

If we disregard the government budget and all constraining factors for a moment, the optimal level of $Z_{1}$ from the ruler's point of view is the solution to the first-order condition: ${ }^{10}$

$$
-e^{\prime}(|\Delta Z|) \cdot \frac{\partial|\Delta Z|}{\partial Z_{1}^{*}}+\delta\left[R_{1}^{\prime}\left(Z_{1}^{*}\right)+M_{1}^{\prime}\left(Z_{1}^{*}\right)\right]=0
$$

This condition relates the basic intuition behind the paper; investment in property rights institutions entails a trade-off for the ruler between the direct cost of effort $e(|\Delta Z|)$ and the indirect cost of lower expropriated rents $R_{1}\left(Z_{1}^{*}\right)$ on the one hand, and the benefits of greater dividends from the modern sector on the other.

\footnotetext{
${ }^{9}$ Deliberate institutional differences between a formal and an informal sector are modelled in Olsson and Congdon Fors (2004).

${ }^{10}$ Note that $\frac{\partial|\Delta Z|}{\partial Z_{1}^{*}}>0$ if $Z_{1}^{*}>Z_{0}$.
} 


\subsection{Functional form}

With the general form above, however, we cannot derive an explicit solution for $Z_{1}^{*}$ or indeed say much else of interest. We will therefore specify a functional form of the utility function and of the government budget constraint that we believe capture the central aspects of the ruler's investment decision.

Starting with the appropriable rents $R_{t}$, we mentioned earlier that these can most easily be thought of as proceeds from state-owned natural resource companies. ${ }^{11}$ Let us assume that there is a total flow of rents $r_{t}$ during period $t=(0,1)$. For simplicity, we choose to model them as exogenous incomes that are generated without using any inputs and that rents are expected to be stable over time; $r_{0}=E_{0}\left(r_{1}\right)=r$. Since the companies are state-owned, all rents are supposed to flow into the government budget. However, the predatory ruler will attempt to confiscate rents for his personal enrichment. The amount that the ruler can lay his hands on $R_{t}$ depends on the existing level of property rights institutions. We assume that

$$
R_{t}=\max \left(\frac{\left(\bar{Z}-Z_{t}\right) r}{\bar{Z}}, 0\right)
$$

where $\bar{Z}$ is a critical level of institutions beyond which rent appropriation is impossible. The 'max' sign above means that if $Z_{t}>\bar{Z}$, then $R_{t}=0 .{ }^{12} \mathrm{We}$ will assume throughout that $Z_{t}<\bar{Z}$ which arguably is the normal case for the developing countries that we have in mind. The amount of rents that are not expropriated by the ruler $Z_{t} r / \bar{Z}$ flow into the government budget, as will be shown below.

The ruler's second source of personal revenue comes from interests in the private sector. To explain how such an ownership has been obtained is beyond the scope of this article. ${ }^{13}$ As a share-holder, the ruler gets his part of total dividends; $M_{t}=\eta \Pi_{t}$ where $\eta<0.5$. The assumption of $\eta<0.5$ means that the ruler's holdings are relatively small, at least smaller than to give

\footnotetext{
${ }^{11}$ See Acemoglu, Johnson, and Verdier (2003) for a similar assumption. Real world examples of more or less state-controlled mining companies are Gecamines (copper) and MIBA (diamonds) in former Zaire, Debswana (diamonds, joint venture with De Beers) in Botswana, Endiama (diamonds) in Angola, and ZIMCO in Zambia. As mentioned above, we believe that marketing boards such as that for cocoa in Ghana might also serve as a source of easily appropriable rents (Bates, 1981).

${ }^{12}$ This reflects the idea that diversion of natural resource rents in developed countries like Canada, Australia, or the United States do not seem to enter the ruler's objective function.

${ }^{13}$ Evidence from Kenya and an analysis of the ruling elite's private ownership patterns are discussed at length in for instance Bigsten and Moene (1996) where the phenomenon is referred to as 'straddling'.
} 
him a majority ownership in the private sector. We further assume that $\eta$ is uncorrelated with $Z_{t}$.

Profits in the modern sector are given by

$$
\Pi_{t}=p_{t} Q_{t}-w L_{m, t}=p_{t} Z_{t} L_{m, t}^{\beta}-w_{t} L_{m, t}
$$

The quality of property rights institutions $Z_{t}$ increases modern sector output $Q_{t}$ linearly like a (Hicks neutral) total factor productivity variable. $L_{m, t}$ is labor supply to the modern sector at period $t$, and $\beta<1$ gives the (diminishing) returns to labor. Labor supply is treated as exogenous and fixed in this section so that $L_{m, t}=L_{m}$ but will be made endogenous below. Workers are paid a wage rate $w_{t}$ which is equivalent to the value marginal product; $w_{t}=p_{t} Z_{t} \beta L_{m, t}^{\beta-1}$. In other words, modern sector labor will be more productive on the margin (and will be better compensated) if property rights institutions are strong. The price of modern sector output is $p_{t}$. Below we will specify the price level to be $p_{0}=p_{1}=1$.

In summary, the ruler's personal revenue from the modern sector will be

$$
M_{t}=\eta \Pi_{t}=\eta Z_{t} L_{m}^{\beta}(1-\beta)
$$

The ruler's disutility of effort is an increasing function of the deviation from status quo:

$$
e(|\Delta Z|)=\frac{\theta\left(Z_{1}-Z_{0}\right)^{2}}{2}=\frac{\theta(\Delta Z)^{2}}{2}
$$

where $\theta>0$ indicates the degree of effort required to carry out changes in property rights institutions. The assumption of a quadratic function ensures that investment and disinvestment are equally costly and implies that the ruler has a kind of status quo bias. Whereas the first derivative with respect to $Z_{1}$ can have any sign, the second derivative is unambiguously positive at $\theta>0$. This means that there is an increasing marginal disutility of institutional change. What this is intended to show is that institutional changes will require more and more effort on the margin as $|\Delta Z|$ increases and hence give rise to a greater and greater utility loss.

All in all, these assumptions give us a more detailed functional form of 
the ruler's objective function in (1):

$$
\begin{aligned}
U_{r}= & \left(1-\frac{Z_{0}}{\bar{Z}}\right) r+\eta Z_{0} L_{m}^{\beta}(1-\beta)-\frac{\theta\left(Z_{1}-Z_{0}\right)^{2}}{2}+ \\
& +\delta\left[\left(1-\frac{Z_{1}}{Z}\right) r+\eta Z_{1} L_{m}^{\beta}(1-\beta)\right]
\end{aligned}
$$

In maximizing personal revenue, the ruler has to take into consideration not only the legal constraints but also the fiscal constraints as given by the government budget. We will assume that in order to stay in power for more than one period, the ruler has to supply a fixed quantity of public goods $G$. This quantity includes the costs of police, defense, physical infrastructure, and basic government administration.

The level of $G$ might also be regarded as an indicator of the strength of one-man-rule. With a given revenue flow, a low $G$ means that the ruler has a relatively great degree of freedom in deciding himself what institutions to create and how much to spend on public goods. Conversely, a high $G$ means that the ruler is highly constrained in the process of institutional reform and that he is obliged to satisfy rather ambitious goals in terms of public goods provision in order to avoid being thrown out of office. ${ }^{14}$ In the second period, the ruler does not take the government budget into account in his maximization problem since he cannot seek re-election for yet another period and therefore has no incentive for fulfilling his obligations. The ruler is thus only partially committed to fiscal discipline.

A more long-term type of government expenditure is institutional reform. As in most of the literature on adjustment costs in investment, the costs of institutional investment or disinvestment are a convex function of $\Delta Z$ : $\psi\left(Z_{1}-Z_{0}\right)^{2} / 2$ where $\psi>0$. The second derivative is simply $\psi>0$, implying an increasing marginal cost. In order to reap the benefits of property rights investment, the ruler must be able to credibly enforce these rights. That entails investment in a number of 'supporting' institutions, e.g. court systems, property registration offices, etc. If the ruler chooses to disinvest, on the other hand, he will be faced with the costs of dismantling the existing structures and probably also with the cost of compensating the losers from such a reform in some way. ${ }^{15}$

\footnotetext{
${ }^{14}$ See Aghion et al (2004) for a model of an endogenously determined political insulation from the people.

${ }^{15}$ It might be argued that disinvestment in property rights institutions is less costly than investment. A way to formalize this notion would be to include a $\psi^{\prime}<\psi$ for disinvestment costs. In the extreme case, one could have a $\psi^{\prime}=0$ which would imply that a worsening of
} 
Government revenue has two sources; the non-expropriated rents from the natural resource sector $Z_{0} r / \bar{Z}$ and a proportional income tax on workers in the modern sector $t w L_{m}=t Z_{0} \beta L_{m}^{\beta}$. The marginal tax rate $t$ might be thought of as the (exogenously given) revenue-maximizing tax rate as in a Laffer-curve. The governmental budget restriction in the initial period states that fixed government outlay plus the costs of property rights investment or disinvestment must not exceed revenue, i.e.:

$$
G+\frac{\psi\left(Z_{1}-Z_{0}\right)^{2}}{2} \leq t Z_{0} \beta L_{m}^{\beta}+\frac{Z_{0} r}{Z}
$$

We assume for the remainder of the article that $G<t Z_{0} \beta L_{m}^{\beta}+Z_{0} r / \bar{Z}$ so that the ruler always has some scope for institutional reform. This budget restriction implies that the optimal level of property rights institutions is defined in the interval $Z_{1}^{*} \in\left[\max \left(0, \hat{Z}_{1}^{-}\right), \hat{Z}_{1}^{+}\right]$where

$$
\hat{Z}_{1}^{-}=Z_{0}-\sqrt{\frac{2\left(t Z_{0} \beta L_{m}^{\beta}+\frac{Z_{0} r}{Z}-G\right)}{\psi}} \gtreqless 0
$$

while the upper boundary of property rights in period 1 is

$$
\hat{Z}_{1}^{+}=Z_{0}+\sqrt{\frac{2\left(t Z_{0} \beta L_{m}^{\beta}+\frac{Z_{0} r}{Z}-G\right)}{\psi}}>0 .
$$

Note that the scope for reform in either direction increases with $r$ and $Z_{0}$ and decreases with $\psi$ and $G$. The 'max'-term defining the lower bound of $Z_{1}^{*}$ reflects the constraint that the actual $Z_{1}^{*}$ is necessarily non-negative whereas a negative institutional level might be financially viable (i.e. if $\hat{Z}_{1}^{-}<0$ ).

\subsection{Optimal institutional change}

The utility function and the governmental budget constraint form a maximization problem for the ruler

$$
\max _{Z_{1}} U_{r} \quad \text { subject to } \psi\left(Z_{1}-Z_{0}\right)^{2} / 2 \leq t Z_{0} \beta L_{m}^{\beta}+\frac{Z_{0} r}{Z}-G \text { and } Z_{1} \geq 0
$$

By setting up a Lagrangean function $\Gamma$ with a multiplier $\lambda$, we can derive

institutions is costless. However, we do believe that it is reasonable to assume that rulers are always somewhat constrained from destroying property rights completely. 
the following Kuhn-Tucker first-order conditions:

$$
\begin{gathered}
\frac{\partial \Gamma}{\partial Z_{1}}=-\theta\left(Z_{1}^{*}-Z_{0}\right)-\frac{\delta r}{\bar{Z}}+\delta \eta L_{m}^{\beta}(1-\beta)-\lambda \psi\left(Z_{1}^{*}-Z_{0}\right) \leq 0 \\
\frac{\partial \Gamma}{\partial \lambda}=t Z_{0} \beta L_{m}^{\beta}+\frac{Z_{0} r}{Z}-G-\psi\left(Z_{1}^{*}-Z_{0}\right)^{2} / 2 \geq 0 \\
\frac{\partial \Gamma}{\partial \lambda} \cdot \lambda=0 ; \quad \frac{\partial \Gamma}{\partial Z_{1}} \cdot Z_{1}=0
\end{gathered}
$$

The third line shows the complementary slackness conditions. The secondorder condition for maximum is fulfilled since the Lagrangean function is strictly concave in the relevant range $Z_{1}>0$.

The problem above implies that we can characterize the set of solutions in the following Lemma:

Lemma 1 The maximization problem in (10) has four potential unique solutions:

$$
Z_{1}^{*}:\left\{\begin{array}{lll}
=0 & \text { if } Z_{1}^{\text {opt }}<0 & \text { and } \lambda=0 \\
=\hat{Z}_{1}^{-}>0 & \text { if } Z^{\text {opt }} \leq \hat{Z}_{1}^{-} & \text {and } \lambda=\hat{\lambda}^{-} \geq 0 \\
=Z_{1}^{\text {opt }} & \text { if } \hat{Z}_{1}^{-}<Z_{1}^{\text {opt }}<\hat{Z}_{1}^{+} & \text {and } \lambda=0 \\
=\hat{Z}_{1}^{+} & \text {if } Z_{1}^{\text {opt }} \geq \hat{Z}_{1}^{+} & \text {and } \lambda=\hat{\lambda}^{+} \geq 0
\end{array}\right.
$$

where $\hat{Z}_{1}^{-}$and $\hat{Z}_{1}^{+}$are given by (8) and (9) respectively,

$$
Z_{1}^{o p t}=Z_{0}+\frac{\delta}{\theta}\left(\eta L_{m}^{\beta}(1-\beta)-\frac{r}{Z}\right)
$$

and

$$
\hat{\lambda}^{-}=\left(\frac{Z^{o p t}-Z_{1}^{-}}{\hat{Z}_{1}^{-}-Z_{0}}\right) \frac{\theta}{\psi} ; \quad \hat{\lambda}^{+}=\left(\frac{Z^{o p t}-Z_{1}^{+}}{\hat{Z}_{1}^{+}-Z_{0}}\right) \frac{\theta}{\psi}
$$

Proof. The results follow from straightforward manipulations of the firstorder conditions.

The first two solutions (i)-(ii) represent lower boundary extrema where the ruler disinvests in property rights institutions as much as he can afford, (iii) is an interior maximum with positive or negative investment, and (iv) is an upper boundary solution where the ruler uses all available government means for positive investment. The zero solution in (i) might only arise when $\hat{Z}_{1}^{-}<0$, as discussed above.

The term $Z_{1}^{\text {opt }}$ is given by the unconstrained maximum $\left.\frac{U_{r}}{\partial Z_{1}}\right|_{Z_{1}=Z_{1}^{\text {opt }}}=$ 0 . This value might or might not be attainable depending on the level of 
affordable reforms. The Lagrange multipliers $\hat{\lambda}^{-}$and $\hat{\lambda}^{+}$reflect the shadow value of net government revenue in case of constrained boundary solutions.

The solutions derived in Lemma 1 might be used to express the following intuitive results:

Proposition 2 (a) The ruler is more likely to strengthen (weaken) property rights institutions if $\eta$ and $L_{m}$ are high (low) and if $r$ and $\theta$ are low (high).

(b) In the case of positive boundary solutions, the change in the strength of property rights institutions in either direction increases with $t, r, L_{m}$ and $Z_{0}$ and decreases with $G$ and $\psi$.

Proof. (a) Whether institutions are strengthened or weakened is determined by the sign of $Z_{1}^{\text {opt }}-Z_{0}=\frac{\delta}{\theta}\left(\eta L_{m}^{\beta}(1-\beta)-\frac{r}{\bar{Z}}\right)$. A high $\eta$ and $L_{m}$ and a low $r$ imply that a positive sign is likely, and vice versa.

(b) From (8) and (9), we know that the greatest feasible institutional change in either direction is $\hat{Z}_{1}^{+}-Z_{0}=Z_{0}-\hat{Z}_{1}^{-}=\sqrt{2\left(t Z_{0} \beta L_{m}^{\beta}+\frac{Z_{0} r}{\bar{Z}}-G\right) / \psi}>$ 0 . From this expression, it is easily seen that the result in $(b)$ applies

In the case of $Z_{1}^{*}=\hat{Z}_{1}^{-}$as in (ii) of Lemma 1 , the ruler is totally committed to destroying existing institutions. The proposition shows that this scenario might arise when the ruler's interests in the modern $\eta$ sector are small and when the rent flow $r$ is large. The greater are $r, t, L_{m}$ and $Z_{0}$ at this equilibrium, the stronger is the government budget and the ruler can afford an even greater weakening of institutions. This 'income effect' might however be balanced by the fact that a weakening of property rights is less likely if $L_{m}$ increases according to $(a)$. A greater $G$ - i.e. a smaller autonomy for the ruler - will in this equilibrium mean a smaller deterioration in institutions.

When we have an interior solution such that $Z_{1}^{*}=Z_{1}^{\text {opt }}$, then the optimal level of institutions in period 1 will depend positively on the 'inherited' level of institutions in period 0 . However, if we look at institutional change as in Proposition 2, it is easily seen that a weakening of property rights is more likely if the rent flow $r$ is large. ${ }^{16}$ In other words, the model predicts that countries with a relatively substantial rent flow at independence should face a worsening of property rights institutions. The logic is of course that high rents will imply that a kleptocratic ruler's opportunity costs of installing stronger property rights are high since a strong protection against expropriation will mean lower rents for himself. However, apart from this 'substitution effect' of

\footnotetext{
${ }^{16}$ More precisely, there will be a disinvestment in institutions if $r>\eta L_{m}^{\beta}(1-\beta) \bar{Z}$.
} 
an increase in $r$, rents also have an income effect via the budget constraint, as discussed above.

In the interior solution, $Z_{1}^{*}$ further increases with $\eta$ and $L_{m}$. The greater the ruler's interests in the modern sector and the greater the value generated from this sector, the greater is the likelihood of a positive change in secondperiod property rights institutions, as one might expect.

In the upper boundary solution where $Z_{1}^{*}=\hat{Z}_{1}^{i}$, the ruler spends every available penny in the government budget on improving property rights. The reason is simply that his marginal utility of $Z_{i}$ is positive in the whole feasible range. This 'good' outcome is therefore more likely when the modern sector is relatively important for the ruler's personal enrichment, i.e. when $\eta$ and $L_{m}$ are high and $r$ is low.

From (9), we see that $Z_{1}^{*}$ increases with $r$ in the upper boundary solution due to the income effect since an increase in $r$ shifts the budget constraint further out. However, an increase in $r$ also decreases the marginal utility of property rights investments, which is the force behind the substitution effect of $r$. At a certain level of $r$, an interior solution will arise in which case an increase in $r$ will lower the optimal level of property rights. ${ }^{17}$ Thus, all else equal, the income effect of increases in $r$ will dominate in the upper boundary solution if such increases start at very low levels of $r$, whereas beyond a certain level, the substitution effect of a higher $r$ will dominate. It is also interesting to note that in this good equilibrium, a smaller fiscal autonomy for the ruler (a higher $G$ ) will imply a lower level of property rights institutions since the discretionary part of the budget shrinks. Similarly, high costs of institutional change - reflected by high levels of $\theta$ and $\psi$ - will inevitably result in small deviations from $Z_{0} \cdot{ }^{18}$

If total output in the country is measured as modern production plus the official or non-diverted flow of rents from the natural resource sector, then we can write $Y_{t}=Q_{t}+Z_{t} r_{t} / \bar{Z}$. The growth rate of the economy in the case of an interior solution will therefore be

$$
\frac{Y_{1}-Y_{0}}{Y_{0}}=\frac{Z^{o p t}-Z_{0}}{Z_{0}}=\frac{\delta}{Z_{0} \theta}\left(\eta L_{m}^{\beta}(1-\beta)-\frac{r}{Z}\right) \gtreqless 0 .
$$

The growth rate is thus negatively related to the flow of rents $r$. The negative marginal effect on growth of an increase in $r$ decreases in absolute terms with

\footnotetext{
${ }^{17}$ This level of $r$ is reached when $\lambda^{+}=0$ which happens when $Z_{1}^{\text {opt }}(r, \cdot)=\hat{Z}_{1}^{+}(r, \cdot)$.

${ }^{18}$ The equations above show that both $Z_{1}^{\text {opt }}-Z_{0}$ and $\hat{Z}_{1}^{+}-Z_{0}=Z_{0}-\hat{Z}_{1}^{-}$will approach zero as $\theta$ and $\psi$ approach infinity.
} 
$Z_{0}$, implying that countries with relatively good initial institutions should experience smaller adverse effects of a high $r$.

The corresponding growth rate for a country that optimally fully utilizes the government budget for positive investment is

$$
\frac{Y_{1}-Y_{0}}{Y_{0}}=\frac{\hat{Z}_{1}^{+}-Z_{0}}{Z_{0}}=\frac{\sqrt{2\left(t Z_{0} \beta L_{m}^{\beta}+\frac{Z_{0} r}{Z}-G\right) / \psi}}{Z_{0}}>0 .
$$

As mentioned above, for this category of countries in the good equilibrium, natural resources do not constitute a curse. On the contrary, growth will increase with an increase in $r$. These findings perhaps contribute to explaining the results from the empirical growth literature that countries with good institutions seem to be able to escape the 'curse of natural resources' (Mehlum et al, 2002). However, as shown above, beyond a certain level of $r$, an interior solution will arise and the (institutions-weakening) substitution effect will start to dominate.

\section{Extensions}

In this section, we will extend our basic model to account for the effects of endogenous labor supply, natural resource booms and declines, foreign aid, trade liberalization, and impediments to institutional efficacy.

\subsection{Endogenous labor supply}

In the derivations above, labor supply $L_{m}$ was assumed to be exogenously given and fixed throughout the two periods. This is not a totally satisfactory assumption since it can be easily imagined that labor supply should depend on for instance the tax rate and, perhaps more interestingly, on the quality of institutions in the modern sector. In this section, we will therefore derive labor supply endogenously and analyze how this alters the results from the previous section. We will assume that the decisions about institutional choice and labor supply are made as in a sequential game with the ruler acting as a leader whose supply of property rights institutions is taken as given by the workers.

Let us assume that the ruler's objective function is as in (6). Let us also postulate that there is only one group of workers with the linear utility 
function

$$
U_{l}\left(L_{m, t}\right)=(1-t) Z_{t} \beta L_{m, t}^{\beta}+\gamma\left(L-L_{m, t}\right)+G \text { for } t=(0,1)
$$

In each of the two periods, the working part of the population receives utility from after-tax labor income $(1-t) Z_{t} \beta L_{m, t}^{\beta}$, from leisure or informal household production $\gamma\left(L-L_{m, t}\right)$, and from the public goods $G$ provided by the ruler. The only new parameters here are $L$ which is the fixed total endowment of labor resources, and $\gamma>0$ that reflects the marginal utility (or productivity) of household production. Note that property rights do not affect the output of informal household production. ${ }^{19}$

The workers maximize $U_{l}$ with labor supply $L_{m, t}$ as the control variable, taking $Z_{t}$ as given. From the usual first-order conditions, we find that the equilibrium levels will be

$$
L_{m, t}^{*}=\left(\frac{(1-t) Z_{t} \beta^{2}}{\gamma}\right)^{\frac{1}{1-\beta}}
$$

Thus labor supply in period $t$ will be positively associated with the strength of property rights institutions in period $t$. This should make sense; the greater the levels of $Z_{t}$, the greater the worker's marginal product and the greater his or her labor supply to the modern sector. Conversely, the greater the utility from household production $\gamma$, the lower the supply of modern sector labor.

The ruler realizes by backward induction what labor effort that will be supplied to the modern sector and takes this level as given in his own optimization. This means that the ruler's utility function becomes

$$
U_{r}=\sum_{t=0}^{1} \delta^{t}\left(\left(1-\frac{Z_{t}}{Z}\right) r+\eta(1-\beta) \beta^{\frac{2 \beta}{1-\beta}} Z_{t}^{\frac{1}{1-\beta}}\left(\frac{(1-t)}{\gamma}\right)^{\frac{\beta}{1-\beta}}\right)-\frac{\theta\left(Z_{1}-Z_{0}\right)^{2}}{2}
$$

The government budget constraint is still that

$$
G+\frac{\psi\left(Z_{1}-Z_{0}\right)^{2}}{2} \leq t Z_{0}^{\frac{1}{1-\beta}} \beta^{\frac{1+\beta}{1-\beta}}\left(\frac{(1-t)}{\gamma}\right)^{\frac{\beta}{1-\beta}}+\frac{Z_{0} r}{Z}
$$

which in turn implies that the highest attainable level of institutional change

\footnotetext{
${ }^{19}$ This could be the case if informal production does not require significant investment (see, eg, Besley, 1995). A similar assumption is made in Olsson and Congdon Fors (2004).
} 


$$
\hat{Z}_{1}^{+}-Z_{0}=Z_{0}-\hat{Z}_{1}^{-}=\sqrt{\frac{2\left(t Z_{0}^{\frac{1}{1-\beta}} \beta^{\frac{1+\beta}{1-\beta}}\left(\frac{(1-t)}{\gamma}\right)^{\frac{\beta}{1-\beta}}+\frac{Z_{0} r}{Z}-G\right)}{\psi}}>0 .
$$

When the optimization problem is changed in this way, the Kuhn-Tucker first-order conditions become more complicated (see Appendix 1). As visual inspection should make clear, the solution to this optimization problem will depend to a great extent on the levels of the labor elasticity parameter $\beta$ as well as on the other parameters of the model. In order to simplify the analysis without losing focus on the essentials, we will make the following assumptions for the remainder of the analysis:

$$
\beta=2 / 3 ; \quad \delta=\theta=\psi=\gamma=1
$$

The assumption that $\beta=2 / 3$ is standard, i.e. that the share of labour in production is $2 / 3 .{ }^{20}$ The assumption that the remaining parameters are equal to one is a simplification, which in many cases will be relaxed in the subsections below. The greatest attainable change in property rights is thus

$$
\hat{Z}_{1}^{+}-Z_{0}=Z_{0}-\hat{Z}_{1}^{-}=\sqrt{2\left(t Z_{0}^{3} c(1-t)+\frac{Z_{0} r}{Z}-G\right)}
$$

where $c=\frac{32}{243}$.

Further, setting $\beta=2 / 3$ means that the ruler's utility function above becomes a cubic function of $Z_{1}$. Unlike in the exogenous labour supply case, the second-order condition for maximum is not necessarily fulfilled in the endogenous labour supply case since the Lagrangean function is not strictly concave in the relevant range $Z_{1}>0$. Rather, as shown in the Appendix, there are two extreme points, given by the expression

$$
Z_{i}^{l, o p t}=\left\{\begin{array}{l}
Z_{1}^{l, \max }=\frac{1-\sqrt{\left(1-4 \eta d(1-t)^{2}\left(Z_{0}-\frac{r}{Z}\right)\right)}}{2 \eta d(1-t)^{2}} \\
Z_{1}^{l, \min }=\frac{1+\sqrt{\left(1-4 \eta d(1-t)^{2}\left(Z_{0}-\frac{r}{Z}\right)\right)}}{2 \eta d(1-t)^{2}}
\end{array}\right.
$$

where $d=\frac{16}{81}$. Obviously, we can disregard $Z_{1}^{l, m i n}$ as a potential solution to the ruler's optimization problem. Upon inspection of (23), it is clear that we

\footnotetext{
${ }^{20}$ See for instance Krueger and Lindahl (2001) for a discussion of the most plausible 'world' level.
} 
will have different types of solutions for $Z_{1}^{l, m a x}$ depending on the size of the expression under the square root sign. Appendix 2 characterizes in detail the solutions for $Z_{1}^{l, m a x}$ and for $Z_{1}^{*}$. The analytically most interesting scenario arises when $Z_{0}-\frac{r}{Z}>0$ and the expression under the square root sign ranges between zero and one, which ensures that $Z_{1}^{l, m a x}>0$. Figures $2 \mathrm{a}$ and $2 \mathrm{~b}$ show two types of solutions with this feature. In these cases, it is also evident that $Z_{1}^{l, m a x}<Z_{1}^{l, m i n}$. The local minimum also provides us with important information: At levels higher than $Z_{1}^{l, m i n}$, investment in property rights once again starts to yield utility gains for the ruler.

Now that we have established the local maximum and the two constrained cases, it remains to determine what the optimal solution to the ruler's maximization problem will actually be. The optimal solution depends on the relationship between the constrained solutions and the unconstrained local maximum, and the utility derived by the ruler from each. In Appendix 2, all possible equilibria and the conditions associated with them are characterized formally.

On a more intuitive level, there are as before four potential solutions: (i) $Z_{1}^{*}=0$, (ii) $Z_{1}^{*}=\hat{Z}_{1}^{-}$, (iii) $Z_{1}^{*}=Z_{1}^{l, m a x}$, or (iv) $Z_{1}^{*}=\hat{Z}_{1}^{+}$. In case (i), the ruler's optimal solution is to dismantle institutions completely. While this would then imply that wages fall to zero, labour leaves the modern sector completely and the state apparatus dissolves, one could view it as a scenario where the ruler appropriates all available rents and flees the country. In reality, we believe that this scenario is improbable. In (ii), the ruler weakens property rights as much as he can afford whereas and interior maximum is optimally chosen in (iii). Whether the latter involves a strengthening or a weakening or institutions is not clear but depends on the parameters. This kind of equilibrium (with a worsening of property rights) is illustrated in Figure 2a. (iv) shows the upper boundary solution, which might arise in four different cases, for instance when $Z_{1}^{l, m a x}>\hat{Z}_{1}^{+}$. A noteworthy feature is further that $Z_{1}^{l, m a x}$ might not be the optimal choice even when it is affordable. As Figure $2 \mathrm{~b}$ shows, $\hat{Z}_{1}^{+}$might give a higher utility than $Z_{1}^{l, \text { max }}$ since the utility function starts increasing again beyond the minimum.

If we are to make a general characterization, the results in the endogenous labor supply case will be similar to those above:

Proposition 3 (a) With endogenous labor supply, the ruler is more likely to strengthen (weaken) property rights institutions if $\eta$ and $Z_{0}$ are high (low) and if $r$ and $t$ are low (high). (b) In the case of positive boundary solutions, 
the change of property rights institutions in either direction increases with $r$ and $Z_{0}$ and with $t$ if $t<1 / 2$, and decreases with $G$.

Proof. (a) Whether institutions are strengthened or weakened is determined by the sign of $Z_{1}^{l, m a x}-Z_{0}=\frac{1}{2 \eta d(1-t)^{2}}\left(1-\sqrt{\left(1-4 \eta d(1-t)^{2}\left(Z_{0}-\frac{r}{\bar{Z}}\right)\right)}\right)-$ $Z_{0}$. A straightforward manipulation of this expression shows that $Z_{1}^{l, m a x}-$ $Z_{0}>0$ if $1-2 \eta d(1-t)^{2} Z_{0}>\sqrt{\left(1-4 \eta d(1-t)^{2}\left(Z_{0}-\frac{r}{Z}\right)\right)}$. By squaring both sides, we receive $1-4 \eta d(1-t)^{2} Z_{0}+\left(2 \eta d(1-t)^{2} Z_{0}\right)^{2}>1-$ $4 \eta d(1-t)^{2}\left(Z_{0}-\frac{r}{Z}\right)$, which in turn implies that $\eta d(1-t)^{2} Z_{0}^{2}>\frac{r}{\bar{Z}}$. Thus $Z_{1}^{l, m a x}-Z_{0}>0$ if $\eta d(1-t)^{2} Z_{0}^{2}>\frac{r}{Z}$, which is the essence of $(a)$.

(b) From (22), we know that the greatest feasible institutional change in either direction is $\hat{Z}_{1}^{+}-Z_{0}=Z_{0}-\hat{Z}_{1}^{-}=\sqrt{2\left(t Z_{0}^{3} c(1-t)+\frac{Z_{0} r}{Z}-G\right)}>0$. From this expression, it is easily seen that the results in $(b)$ regarding $r$, $Z_{0}$, and $G$ apply. Since $t<1$, the multiplicative term $t(1-t)$ receives its maximum at $t=1 / 2$.

As before, positive (negative) changes are more likely if $\eta$ is large (small) and $r$ is small (large). If the imbalance between the incentives for strengthening property rights $\left(\eta d(1-t)^{2} Z_{0}^{2}\right)$ and the incentives for weakening them $(r / \bar{Z})$ is large in either direction, a boundary solution is more likely where the results in (b) will apply. A difference from the previous section is that a strengthening of property rights is more likely if the level of inherited institutions $Z_{0}$ is high. This implies a kind of path dependence: Countries with strong property rights at independence will invest in even stronger rights whereas the reverse will be true for more weakly institutionalized colonies. The logic is that better intitial institutions means lower costs of additional investments in strengthening property rights. Further, since $r$ and $Z_{0}$ affect both the unconstrained and the constrained solutions, they might have both income and substitutions effects, as discussed above.

The proposition shows that a rise in $\eta$ only has an impact on the maximum whereas $G$ only affects the constrained solutions. An interesting case might occur if two otherwise identical countries have slightly different levels of required public goods, $G$. Let us assume that for some reason, one of the countries (country 1) gives a larger discretionary power to the ruler than in country 2 so that $G^{1}<G^{2}$. Then, if the situation is as in Figure 3, this means that country 1 will optimally be at the upper boundary solution whereas country 2 will be stuck at the lower boundary. This illustrates the 
notion that even small differences between countries might give drastically different outcomes regarding the optimal structure of institutions.

As with the exogenous labour supply case above, total output in the country is measured as modern production plus the official or non-diverted flow of rents from the natural resource sector; $Y_{t}=Q_{t}+Z_{t} r / \bar{Z}$. The equilibrium level of output for the second period is thus

$$
\begin{aligned}
Y_{1}^{*} & =Z_{1}^{*} \cdot\left(L_{m, 1}^{*}\right)^{2 / 3}+\frac{Z_{1}^{*} \cdot r}{\bar{Z}}= \\
& =\left(Z_{1}^{*}\right)^{3} \cdot d(1-t)^{2}+\frac{Z_{1}^{*} \cdot r}{\bar{Z}}
\end{aligned}
$$

where $L_{m, 1}^{*}$ is the equilibrium labor supply derived from (17) and where $Z_{1}^{*}$ is any of the solutions specified above. In the case of an interior solution, comparative statics makes it clear that $Y_{1}$ increases with optimal institutional quality $Z_{1}^{*}=Z_{1}^{l, m a x}$ which, as we know, is positively related with the firstperiod level $Z_{0}$ and with the ruler's share of modern sector ownership $\eta$. The same result regarding $Z_{0}$ (but not $\eta$ ) applies if $Z_{1}^{*}=\hat{Z}_{1}^{+}$. The relationship

with $r$ is more complicated since $Z_{1}^{l, m a x}$ falls with $r$ at the same time as there is a direct positive effect in (24). The end result will hinge on the level of several parameters. If $Z_{1}^{*}=\hat{Z}_{1}^{+}$, it is clear that $r$ has a positive effect via the income effect on $\hat{Z}_{1}^{+}$and thus has an overall positive effect on the income level.

\subsection{Foreign aid}

So far we have assumed that the ruler can only finance changes in property rights institutions through domestic means. There is, however, a possibility that the ruler receives development aid from foreign donors. Ideally, this aid would be ear-marked for institutional development, yielding the following upper budget constraint

$$
\hat{Z}_{1}^{+}=Z_{0}+\sqrt{2\left(t Z_{0}^{3} c(1-t)+\frac{Z_{0} r}{\bar{Z}}+A-G\right)}
$$

where $A$ is foreign aid. Given that $Z_{1}^{*}=\hat{Z}_{1}^{+}$, the effect of aid would therefore be to increase the optimal level of property rights institutions.If $Z_{1}^{*}=Z_{1}^{A \text {,max }}$, on the other hand, the budget constraint is not binding and the ruler may choose to forgo the foreign aid in favour of a lower level of institutions.

If it is the case, on the other hand, that the ruler treats the aid as addi- 
tional rents, then the budget constraint would be

$$
\hat{Z}_{1}^{+}-Z_{0}=Z_{0}-\hat{Z}_{1}^{-}=\sqrt{2\left(t Z_{0}^{3} c(1-t)+\frac{Z_{0}(r+A)}{Z}-G\right)}
$$

so that only $Z_{0} A / \bar{Z}$ is used to make institutional changes. Note that the ruler may also use the foreign aid to disinvest in property rights.

If the ruler does not expect to receive foreign aid in the second period, the optimum solution for the second period is not affected and the aid only gives an income effect in the first period, as well as increased first period utility. On the other hand, if the ruler expected to receive aid in the second period as well, then the aid would act as an increase in rents, and would affect the ruler's optimization in the same way as an increase in $r$, as discussed in subsection 4.1. Hence, foreign aid that is not used for investment in property rights institutions could result in worsening institutions and have a negative impact on economic development. This potential negative effect of aid appears in the theoretical model of Acemoglu, Robinson, and Verdier (2003), and seems to be somewhat supported by empirical evidence (Knack, 2000).

\subsection{Trade liberalization}

International trade is another factor that may influence the ruler's maximization problem. We assume that trade will influence the price of the modern sector output and that a liberalization is usually associated with a fall in modern sector prices. The effect of this price change depends on the timing of the liberalization. Start with the scenario where trade liberalization occurs in the second period, so that $p_{0}=1, p_{1}<1$. Here, the budget constraints will remain the same as in (22), while the equation for the interior maximum becomes

$$
Z_{1}^{l, \max }=\frac{1-\sqrt{\left(1-2 p_{1}^{3} \eta d(1-t)^{2}\left(Z_{0}-\frac{r}{Z}\right)\right)}}{p_{1}^{3} \eta d(1-t)^{2}} .
$$

We can easily confirm that $Z_{1}^{l, m a x}$ increases with $p_{1}$. The intuition is that a lower price level decreases labor supply and makes modern sector production less attractive in relative terms than rent seeking.

If trade liberalization occurs in the first period, and $p_{0}=E\left(p_{1}\right)=p<1$, then the budget constraint becomes

$$
\hat{Z}_{1}^{+}-Z_{0}=Z_{0}-\hat{Z}_{1}^{-}=\sqrt{2\left(t Z_{0}^{3} p^{3} c(1-t)+\frac{Z_{0} r}{Z}-G\right)}
$$


Clearly, a fall in $p$ lowers the maximum feasible change in property rights institutions. However, $Z_{1}^{l, m a x}$ will also increase with $p$ in the same way as in (28). In other words, trade liberalization that is accompanied by a permanently lower price for modern sector goods will weaken property rights institutions if we initially have an interior or an upper boundary solution. The results are of course reversed if a trade liberalization causes an increase in modern sector prices.

\subsection{Impediments to institutional efficacy}

As mentioned in the introduction, Africa in particular faces many obstacles to institutional change, such as low population density, a complex geography, and great ethnic diversity (see for instance Herbst, 2000). These factors can influence the ruler's optimal choice of property rights institutions in two ways. First, it may be that $\theta>1$ (rather than $\theta=1$ as assumed previously). This corresponds to a greater amount of effort being required on the ruler's part to bring about institutional change, with the local maximum defined by

$$
Z_{1}^{\theta, \max }=\frac{\theta-\sqrt{\left(\theta^{2}-2 \eta d(1-t)^{2}\left(\theta Z_{0}-\frac{r}{Z}\right)\right)}}{\eta d(1-t)^{2}} .
$$

The effect of an increase in $\theta$ is to make any change, be it investment or disinvestment, less attractive. ${ }^{21}$ Another possibility is that these obstacles cause $\psi>1$. This corresponds to an increase in the monetary cost of institutional change via the government budget. In this case, the budget constraint is as given in (20). It is directly evident that an increase in $\psi$ will lower the amount of institutional change that is attainable. ${ }^{22}$ In the worst case, high costs of institutional change may compel a ruler to choose a low property rights equilibrium over a high property rights equilibrium.

We have assumed that $Z$ increases modern sector output at a 1:1 ratio. It is possible, however, that the effect of $Z$ on modern sector output is less than one. There is some theoretical support for the notion that the effectiveness of property rights on modern sector output is positively related to the state of technology (Demsetz, 1967; Alchian and Demsetz, 1973), so that low technology may decrease the effectiveness of property rights on modern

\footnotetext{
${ }^{21}$ However, the sign of the partial derivative of (30) with respect to $\theta$ can be either positive or negative.

${ }^{22}$ Whether this results in higher or lower level of $Z_{1}^{*}$ depends on whether the ruler optimally strengthens or weakens property rights institutions.
} 
sector output. Other potential factors include low levels of human capital accumulation, missing markets, limited access to credit, a high degree of ethnic fractionalization and geographical impediments. In this case, output in the modern sector would be $\varepsilon^{3} Z_{0}^{3} d(1-t)^{2}$, where $\varepsilon<1$. This in turn would alter the optimum solution as follows

$$
Z_{1}^{\varepsilon, \max }=\frac{1-\sqrt{\left(1-2 \varepsilon^{3} \eta d(1-t)^{2}\left(\theta Z_{0}-\frac{r}{Z}\right)\right)}}{\varepsilon^{3} \eta d(1-t)^{2}} .
$$

while the budget constraint becomes

$$
\hat{Z}_{1}^{+}-Z_{0}=Z_{0}-\hat{Z}_{1}^{-}=\sqrt{2\left(t Z_{0}^{3} \varepsilon^{3} c(1-t)+\frac{Z_{0} r}{Z}-G\right)} .
$$

The effect of $\varepsilon<1$ is to lower the maximum feasible investment in property rights institutions, while at the same time lowering the level of property rights institutions at which the maximum occurs. Therefore, property rights institutions will be weakened if we initially have an interior or an upper boundary solution when $Z$ increases modern sector output at less than a 1:1 ratio. Finally, an increase in $\gamma$, the marginal productivity of household production, will have the opposite general effect of $\varepsilon$ on the budget constraints and the unconstrained optima. ${ }^{23}$

The above impediments to institutional efficacy all have in common that they restrict the scope of attainable institutional change compared to what would otherwise be the case. Further, in the case when output is adversely affected, the ruler may be more inclined to choose a low level of property rights institutions.

\section{Conclusion}

In this article, we have attempted to model the decision process of property rights (dis)investment by an autocratic ruler. We have been motivated by previous literature that has emphasized the crucial role institutions play in economic development, as well as by institutional changes that have taken place in former European colonies since independence. Further, the model has been motivated by the literature on the 'natural resource curse' and the observation that countries with strong institutions do not seem to suffer from

\footnotetext{
${ }^{23}$ The only difference being that $\gamma$ will occur in quadratic form rather than cubic, as is the case with $\varepsilon$.
} 
this curse.

Indeed, one of the main results of our model is that when labour supply is endogenous, the low property rights institutions equilibrium disappears when initial institutions are relatively greater than the rents for natural resources. Conversely, the model explains why rulers may not invest in property rights institutions even in the absence of natural resource rents. Additionally, we argue that the greater potential for point natural resources and the relatively high cost of property rights institutions investment in larger countries provides a partial explanation for the observed negative relationship between country size and institutional quality. Finally, the model retains a component of institutional persistence, which is present in much of the literature on the origins of institutions in former colonies. Although we have assumed that the ruler is only interested in personal enrichment, one could easily alter the model to fit an altruistic ruler. In this case, the rent appropriation part of the utility function would disappear, and $\eta$ would measure the ruler's willingness to expanding the modern sector.

While the assumption that labour supply to the modern sector is fixed and exogenous is perhaps unrealistic, the endogenous labour supply case may also have shortcomings. It may be unreasonable to assume that labour supply can adjust quickly enough to capture the full benefit of increased property rights. One reason is that human capital is likely to be necessary in the modern sector, and human capital accumulation is a somewhat lengthy process. Therefore, the exogenous labour supply case may reflect a short-run case, whereas the endogenous labour supply case reflects a long-run perspective. A natural extension of this model is to add a further dynamic component where labour supply is a function of property rights and human capital investment.

Further, there is no capital in the model. A possible extension could be to model the joint decision in investing in capital and property rights. As well, access to credit and foreign direct investment surely plays a role in this story, and their inclusion in the model would make for another natural extension. Finally, we have assumed throughout that the ruler makes wise decisions when investing in property rights institutions, and that the result is a growing modern sector. We have not modelled the possibility that the ruler attempts to invest in the modern sector in a way that is detrimental to the economy, such as the pursuit of import substitution strategies or other forms of counter-productive policy-making. 


\section{Appendix}

\subsection{A1}

The Lagrangean for this problem is

$$
\begin{aligned}
\Gamma^{l}= & \sum_{t=0}^{1} \delta^{t}\left(\left(1-\frac{Z_{t}}{Z}\right) r+\eta(1-\beta) \beta^{\frac{2 \beta}{1-\beta}} Z_{t}^{\frac{1}{1-\beta}}\left(\frac{(1-t)}{\gamma}\right)^{\frac{\beta}{1-\beta}}\right)-\frac{\theta\left(Z_{1}-Z_{0}\right)^{2}}{2}+ \\
& +\lambda\left(t Z_{0}^{\frac{1}{1-\beta}} \beta^{\frac{1+\beta}{1-\beta}}\left(\frac{(1-t)}{\gamma}\right)^{\frac{\beta}{1-\beta}}+\frac{Z_{0} r}{\bar{Z}}-G-\frac{\psi\left(Z_{1}-Z_{0}\right)^{2}}{2}\right)
\end{aligned}
$$

with the Kuhn-Tucker first-order conditions

$$
\begin{gathered}
\frac{\partial \Gamma}{\partial Z_{1}}=-\frac{\delta}{Z} r+\delta \eta \beta^{\frac{2 \beta}{1-\beta}} Z_{1}^{\frac{\beta}{1-\beta}}\left(\frac{(1-t)}{\gamma}\right)^{\frac{\beta}{1-\beta}}-\theta\left(Z_{1}-Z_{0}\right)-\lambda \psi\left(Z_{1}-Z_{0}\right) \leq 0 \\
\frac{\partial \Gamma}{\partial \lambda}=t Z_{0}^{\frac{1}{1-\beta}} \beta^{\frac{1+\beta}{1-\beta}}\left(\frac{(1-t)}{\gamma}\right)^{\frac{\beta}{1-\beta}}+\frac{Z_{0} r}{Z}-G-\frac{\psi\left(Z_{1}-Z_{0}\right)^{2}}{2} \geq 0
\end{gathered}
$$

and the complementary slackness conditions

$$
\frac{\partial \Gamma}{\partial \lambda} \cdot \lambda=0 ; \quad \frac{\partial \Gamma}{\partial Z_{1}} \cdot Z_{1}=0 .
$$

Given the parameter simplifications, (33) implies that the interior solutions are

$$
Z_{i}^{l, \text { opt }}=\left\{\begin{array}{l}
Z_{1}^{l, \text { max }}=\frac{1}{2 \eta d(1-t)^{2}}\left(1-\sqrt{\left(1-4 \eta d(1-t)^{2}\left(Z_{0}-\frac{r}{Z}\right)\right)}\right) \\
Z_{1}^{l, \text { min }}=\frac{1}{2 \eta d(1-t)^{2}}\left(1+\sqrt{\left(1-4 \eta d(1-t)^{2}\left(Z_{0}-\frac{r}{Z}\right)\right)}\right)
\end{array}\right.
$$

and that the Lagrangean multipliers are

$$
\hat{\lambda}^{+}=\frac{\eta d\left(\hat{Z}_{1}^{+}\right)^{2}(1-t)^{2}-\frac{r}{Z}}{\left(\hat{Z}_{1}^{+}-Z_{0}\right)}-1
$$

and

$$
\hat{\lambda}^{-}=\frac{\eta d\left(\hat{Z}_{1}^{-}\right)^{2}(1-t)^{2}-\frac{r}{Z}}{\left(\hat{Z}_{1}^{-}-Z_{0}\right)}-1
$$




\subsection{A2}

The expression in (23) implies that there are four distinct possibilities for the local maximum:

$$
Z_{1}^{l, \max }: \begin{cases}=0 & \text { if }\left(Z_{0}-\frac{r}{Z}\right)=0 \\ >0 & \text { if } 0<4 \eta d(1-t)^{2}\left(Z_{0}-\frac{r}{Z}\right)<1 \\ <0 & \text { if }\left(Z_{0}-\frac{r}{Z}\right)<0 \\ \nexists & \text { if } 4 \eta d(1-t)^{2}\left(Z_{0}-\frac{r}{Z}\right)>1\end{cases}
$$

The set of solutions to the maximization problem defined by the Lagrangean function are:

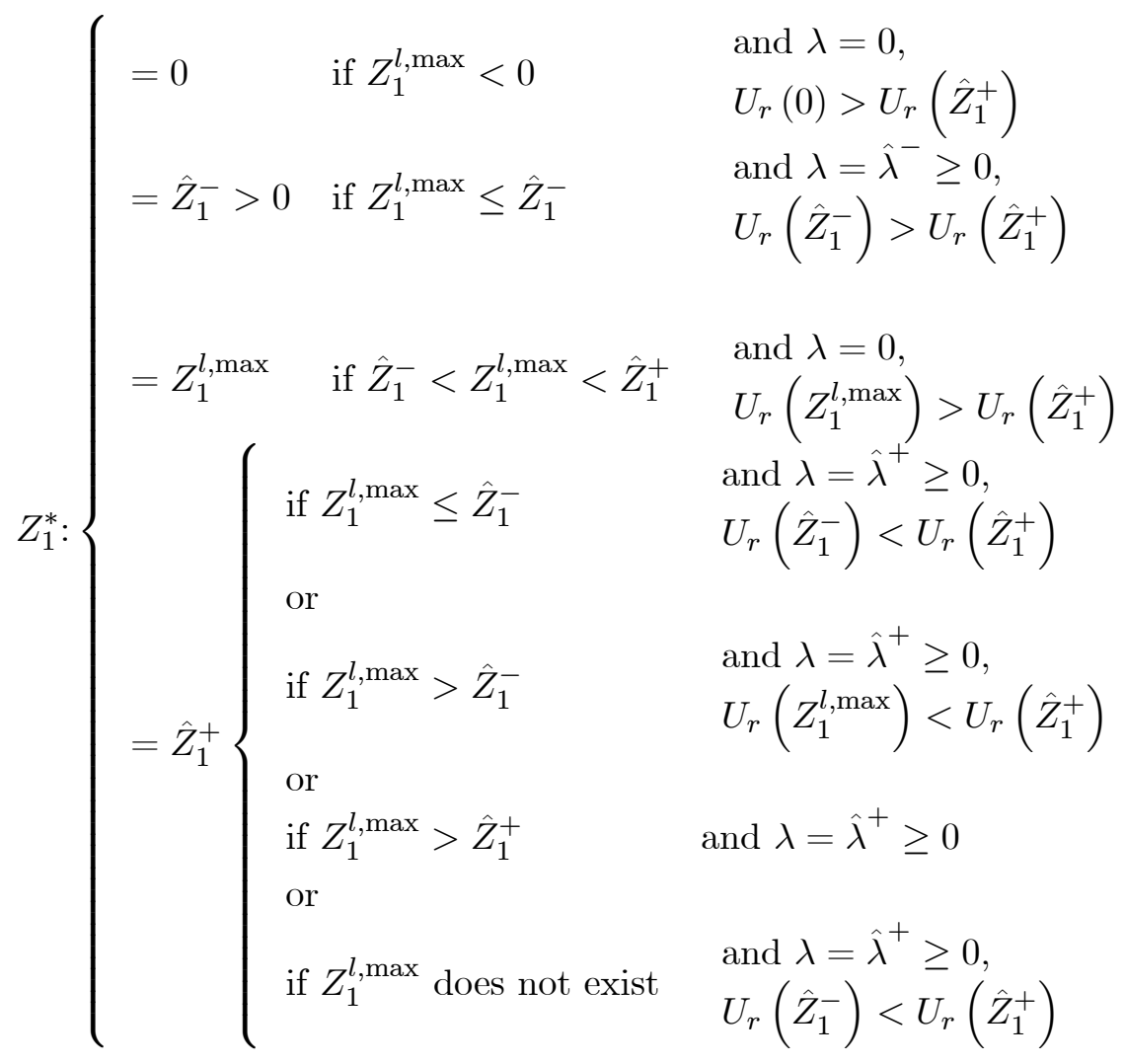

\section{References}

[1] Acemoglu, D. (2003) "The Form of Property Rights: Oligarchic vs. Democratic Societies" MIT, mimeo.

[2] Acemoglu, D. and S. Johnson (2003) "Unbundling Institutions" MIT, mimeo. 
[3] Acemoglu, D., S. Johnson and J.A. Robinson (2001a) "The Colonial Origins of Comparative Development: An Empirical Investigation" American Economic Review 91(5): 1369-1401.

[4] Acemoglu, D., S. Johnson, and J.A. Robinson (2001b) "An African Success Story: Botswana" in D. Rodrik (ed) (2001) Analytical Narratives in Development.

[5] Acemoglu, D., S. Johnson and J.A. Robinson (2002) "Reversal of Fortune: Geography and Institutions in the Making of the Modern World Income Distribution", Quarterly Journal of Economics 117(4): 1231-1294.

[6] Acemoglu, D., S. Johnson, J.A. Robinson, and Y. Tchaicharoen (2003) "Institutional Causes, Macroeconomic Symptoms: Volatility, Crises, and Growth", Journal of Monetary Economics 50: 49-123.

[7] Acemoglu, D., J. Robinson, and T. Verdier (2003) "Kleptocracy and Divideand-Rule: A Model of Personal Rule", NBER Working Papers No. 10136.

[8] Aghion, P., A.Alesina, and F.Trebbi (2004) "Endogenous Political Institutions" Quarterly Journal of Economics 119(2): 565-611.

[9] Alchian, A.A. and H. Demsetz (1973) "The Property Right Paradigm" Journal of Economic History 33(1): 16-27.

[10] Alesina, A. (2003) "The Size of Countries: Does it Matter?" Journal of the European Economic Association 1(2-3): 301-306.

[11] Alesina, A. and Spolaore (1997) "On the Number and Size of Nations" Quarterly Journal of Economics 112(4): 1027-1056.

[12] Alesina, A., A. Devleeschawer, W. Easterly, S. Kurlat, R. Wacziarg (2003) "Fractionalization", Journal of Economic Growth 8: 155-194.

[13] Bates, R.H. (1981) Markets and States in Tropical Africa: The Political Basis of Agricultural Policies, Berkeley: University of California Press.

[14] Bates, R.H. and P. Collier (1993) "The Politics and Economics of Policy Reform in Zambia" in R.H. Bates and A. Krueger (1993)(eds), Political and Economic Interactions in Economic Policy Reform, Oxford: Blackwell, chap 9.

[15] Besley, T. (1995) "Property Rights and Investment Incentives: Theory and Evidence from Ghana" Journal of Political Economy 103(5): 903-937.

[16] Bigsten, A. (2001) "Policy-Making in Resource Rich Countries: Lessons from Zambia" World Economics 2(3): 139-153.

[17] Bigsten, A. and K. Moene (1996) "Growth and Rent Dissipation: The Case of Kenya" Journal of African Economies 5(2): 177-198.

[18] Coase, R.M. (1960) "The Problem of Social Cost" Journal of Law and Economics 3: 1-44. 
[19] Collier, P. and A. Hoeffler (1998) "On the Economic Causes of Civil War" Oxford Economic Papers 50: 563-573.

[20] Demsetz, H. (1967) "Toward a Theory of Property Rights" American Economic Review 57(2): 347-359.

[21] de Soto, H. (2000) The Mystery of Capital: Why Capitalism Triumphs in the West and Fails Everywhere Else. London: Black Swan Books.

[22] Djankov, S., E. Glaeser, R. LaPorta, F. Lopez-de-Silanes, A. Shleifer (2003) "The New Comparative Economics" Journal of Comparative Economics 31: 596-619.

[23] Easterly, W. and R. Levine (1997) "Africa's Growth Tragedy: Policies and Ethnic Divisions" Quarterly Journal of Economics 112(4): 1203-1250.

[24] Easterly, W. and R. Levine (2003) "Tropics, Germs, and Crops: How Endowments Influence Economic Development", Journal of Monetary Economics 50: 3-39.

[25] Firmin-Sellers, K. (1995) "The Politics of Property Rights" American Political Science Review 89(4): 867-881.

[26] Glaeser, E., R. la Porta, F. Lopez-de-Silanes, and A. Shleifer (2004) "Do Institutions Cause Growth?" Journal of Economic Growth 9: 271-303.

[27] Glaeser, E.L. and A. Shleifer (2002) "Legal Origins" Quarterly Journal of Economics 117(November): 1193-1230.

[28] Haas, M. (1999) "A Political History" in M. Haas (ed.) Singapore Puzzle Westport: Greenwood Publishing Group.

[29] Hall, R. and C. Jones (1999) "Why Do Some Countries Produce So Much More Output Than Others?" Quarterly Journal of Economics 114(1): 83-116.

[30] Herbst, J. (2000) States and Power in Africa. Princeton University Press.

[31] Huff, W.G. (1999) "Turning the Corner in Singapore's Development State?" Asian Survey 39(2): 214-242.

[32] Kaufmann, D., A. Kraay, and M. Mastruzzi (2003) "Governance Matters III: Governance Indicators for 1996-2002" World Bank Research Working Paper, Washington D.C.

[33] Knack, Stephen (2000) "Aid Dependence and the Quality of Governance," World Bank, Policy Research Working Paper \#2396, Washington D.C.

[34] Krueger, A.B. and M. Lindahl (2001) "Education for Growth: Why and For Whom?" Journal of Economic Literature 36(December): 1101-1136.

[35] Li, K.W. (2002) Capitalist Development 83 Economism in East Asia : The Rise of Hong Kong, Singapore, Taiwan, \& South Korea. Florence, KY, USA: Routledge. 
[36] Lingle, C. and K. Wickman (1999) "Political Economy" in M. Haas (ed.) Singapore Puzzle Westport: Greenwood Publishing Group.

[37] Mehlum, H., K. Moene, and R. Torvik (2002) "Institutions and the Resource Curse" forthcoming in Economic Journal.

[38] North, D. (1981) Structure and Change in Economic History. New York: W W Norton and Company.

[39] North, D. (1990) Institutions, Institutional Change and Economic Performance. Cambridge University Press.

[40] Nzongola-Ntalaja, G. (2002) The Congo from Leopold to Kabila: A People's History, London: Zed.

[41] Olsson, O. (2004a) "Unbundling Ex-Colonies: A Comment on Acemoglu, Johnson, and Robinson, 2001", Working Papers in Economics No 146, Dept of Economics, Göteborg University.

[42] Olsson, O. (2004b) "Diamonds Are a Rebel's Best Friend", Working Papers in Economics No 156, Dept of Economics, Göteborg University.

[43] Olsson, O. and H. Congdon Fors (2004) "Congo: The Prize of Predation", Journal of Peace Research 41(3): 321-336.

[44] Olsson, O. and D.A. Hibbs (2005) "Biogeography and Long-Run Economic Development" European Economic Review 49(4): 909-938.

[45] Persson, T. (2004) "Forms of Democracy, Policy, and Economic Development" Stockholm University, mimeo.

[46] Sachs, J. (2001) "Tropical Underdevelopment" NBER Working Paper 8119, NBER.

[47] Saideman, S.M. (1997) "Explaining the International Relations of Seccessionist Conflicts: Vulnerability versus Ethnic Ties" International Organization 51(4): 721-753.

[48] Sokoloff, K.L. and S.T. Engerman (2000) "History Lessons: Institutions, Factor Endowments, and Paths of Development in the New World" Journal of Economic Perspectives 14(3): 217-232.

[49] Sonin, K. (2003) "Why the Rich May Favor Poor Protection of Property Rights" Journal of Comparative Economics 31: 715-731.

[50] Svensson, J. (1998) "Investment, Property Rights, and Political Instability: Theory and Evidence" European Economic Review 42(7): 1317-1341.

[51] Tornell, A. (1997) "Economic Growth and Decline with Endogenous Property Rights" Journal of Economic Growth 2: 219-250.

[52] Woolcock, M., L. Pritchett, and J. Isham (2001) "The Social Foundations of Poor Economic Growth in Resource-Rich Countries" in Auty (2001)(ed) Re- 
source Abundance and Economic Development, Oxford University Press, chap 5.

[53] World Bank (2004) World Development Indicators CD-Rom, Washington.

[54] Young, C. (1994) "Zaire: The Shattered Illusion of the Integral State" Journal of Modern African Studies 32(2): 247-263. 
Figure 1: OLS relationship between unexplained variation in Rule of Law and Log Area.

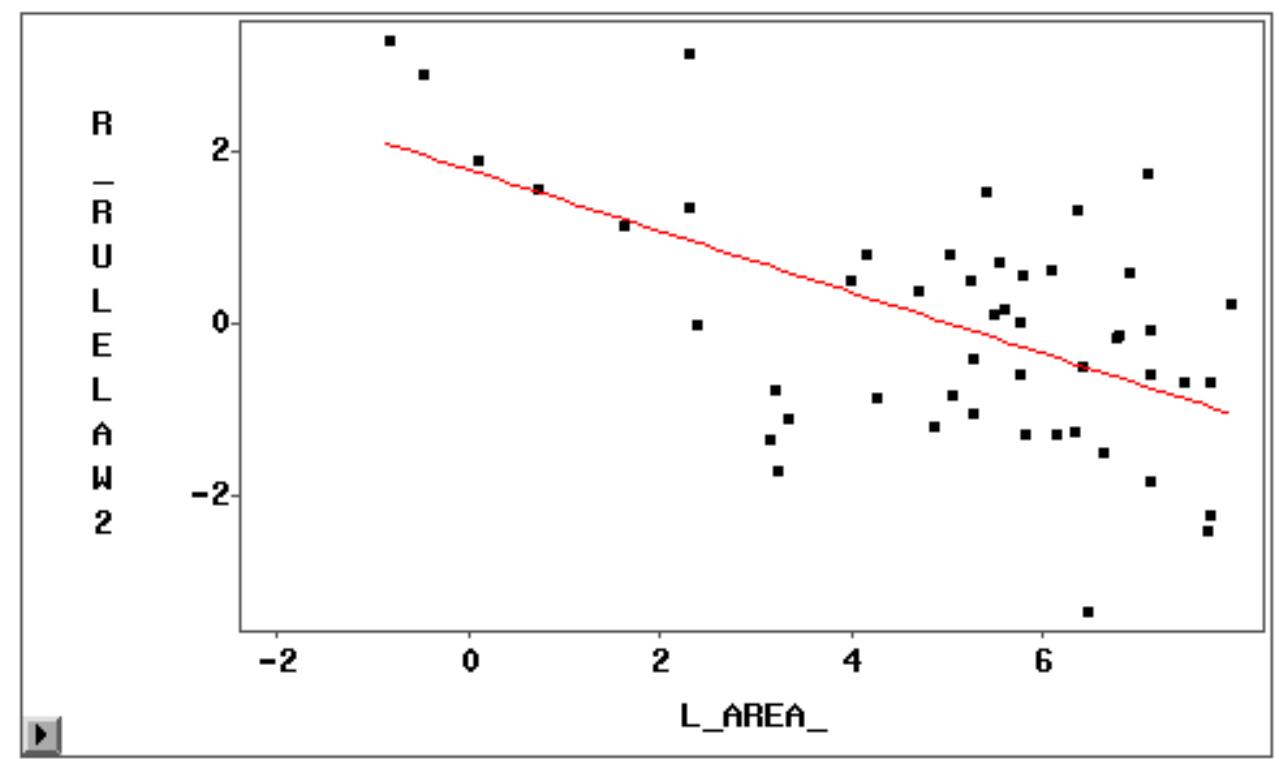

Note: The vertical axis shows the residuals from a regression with Rule of Law in 2002 as the dependent variable and Settler Mortality (AJR, 2001a) as the independent variable. The vertical axis shows the log of country Area (in thousands of kilometers). The estimated equation is Res. Rule of Law $=1.794-0.357(0.076) \times \log$ Area (standard error in parenthesis), $N=49, R^{2}=0.32$. 
Figure 2a: Optimal weakening of property rights with endogenous labor supply.

Interior maximum is optimal: $Z_{1}^{*}=Z_{1}^{l, \max }<Z_{0}$

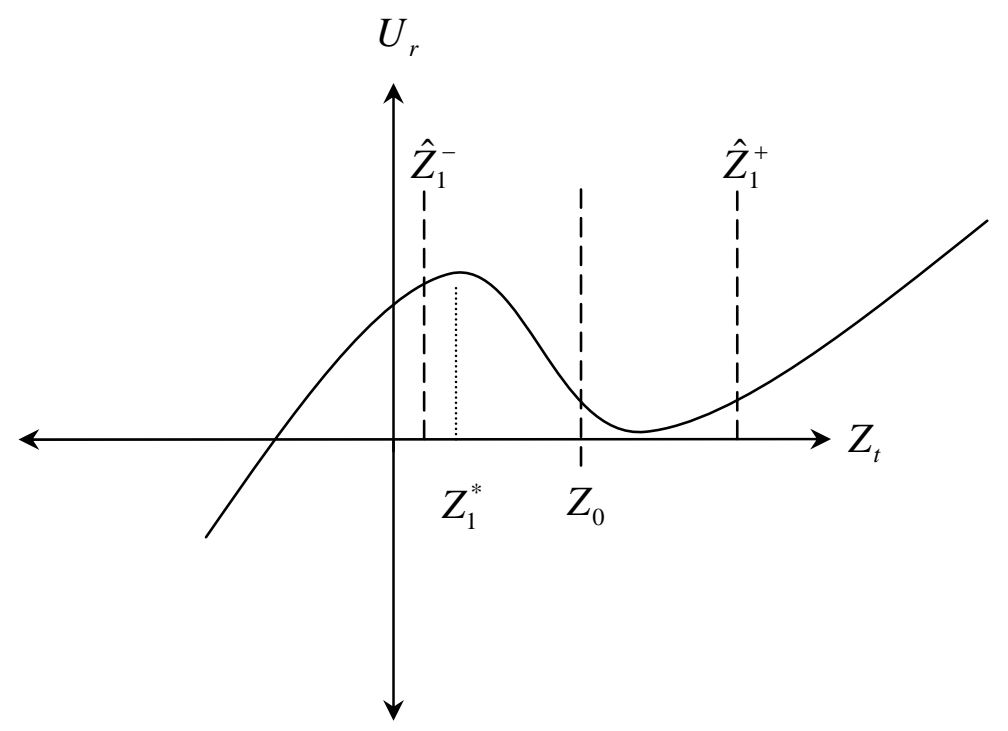

Figure 2b: Optimal strengthening of property rights with endogenous labor supply.

Upper boundary is optimal: $Z_{1}^{*}=\hat{Z}_{1}^{+}>Z_{0}>Z_{1}^{l, \max } ; U_{r}\left(\hat{Z}_{1}^{+}\right)>U_{r}\left(Z_{1}^{l, \max }\right)$

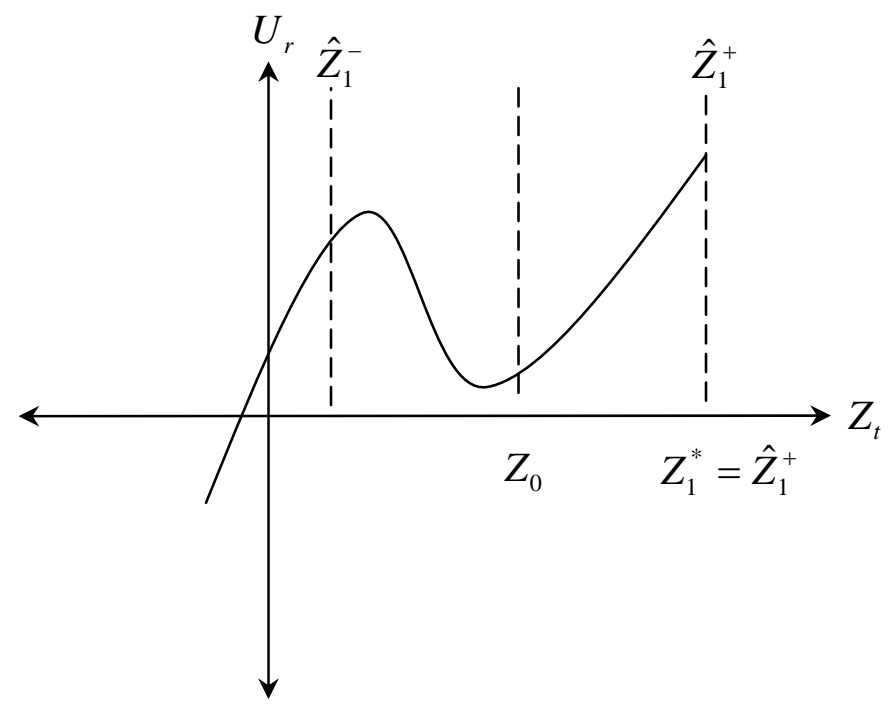


Figure 3: A high and a low equilibrium level of property rights.

$$
Z_{1}^{*}=\hat{Z}_{1}^{-} \text {if } G=G^{2}>G^{1} . Z_{1}^{*}=\hat{Z}_{1}^{+} \text {if } G=G^{1} .
$$

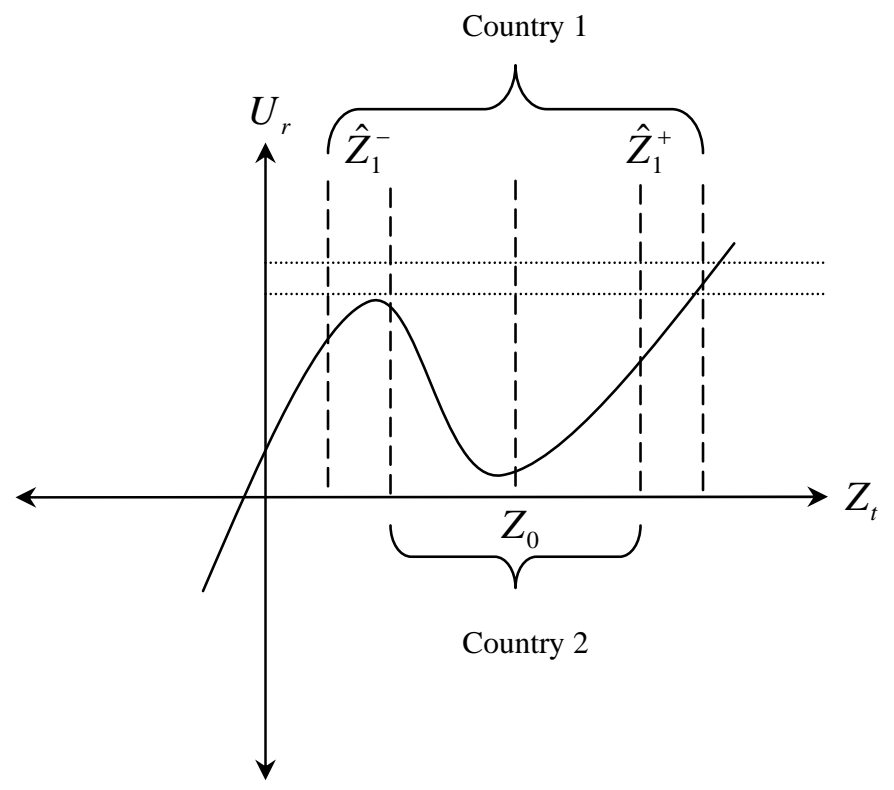


Data Appendix

Country
SINGAPORE
BARBADOS
BAHAMAS
HONG KONG
ANTIGUA AND BARBUDA
SAMOA
MAURITIUS
MACAO
BOTSWANA
DOMINICA
ST. VINCENT AND THE
GRENADINES
MALAYSIA
SEYCHELLES
NAMIBIA
MALDIVES
TRINIDAD AND TOBAGO
ST. KITTS AND NEVIS
ST. LUCIA
GRENADA
TUNISIA
SRI LANKA
CAPE VERDE
MOROCCO
BHUTAN
INDIA
BELIZE
LESOTHO
GHANA
MADAGASCAR
SENEGAL
GABON
KIRIBATI
MARSHALL ISLANDS
VANUATU
MAURITANIA
SURINAME
MALAWI
JAMAICA
FIJI
VIETNAM
BENIN
GUYANA
SAO TOME AND PRINCIPE
TANZANIA
NEPAL
GAMBIA
DJIBOUTI
ERITREA
ZAMBIA
MANAMANA

\begin{tabular}{|c|c|c|}
\hline $\begin{array}{l}\text { Area } \\
\left(1000 \mathbf{k m}^{2}\right)\end{array}$ & $\begin{array}{l}\text { Rule of law } \\
2002\end{array}$ & $\begin{array}{l}\text { Settler } \\
\text { mortality }\end{array}$ \\
\hline 0,61 & 8,50117 & 17,7 \\
\hline 0,43 & 7,85396 & 85 \\
\hline 10,01 & 7,68931 & 85 \\
\hline 1,092 & 7,60098 & 14,9 \\
\hline 0,44 & 7,03386 & .. \\
\hline 2,83 & 6,88291 & .. \\
\hline 2,03 & 6,78156 & 30,5 \\
\hline 0,025 & 6,50322 & .. \\
\hline 566,73 & 6,43839 & .. \\
\hline 0,75 & 6,33267 & .. \\
\hline 0,39 & 6,31732 & .. \\
\hline 328,55 & 6,15343 & 17,7 \\
\hline 0,45 & 6,03860 & .. \\
\hline 823,29 & 5,89535 & .. \\
\hline 0,3 & 5,87732 & .. \\
\hline 5,13 & 5,67744 & 85 \\
\hline 0,36 & 5,66649 & .. \\
\hline 0,61 & 5,66649 & .. \\
\hline 0,34 & 5,55476 & .. \\
\hline 155,36 & 5,54670 & 63 \\
\hline 64,63 & 5,46378 & 69,8 \\
\hline 4,03 & 5,38165 & .. \\
\hline 446,3 & 5,21870 & 78,2 \\
\hline 47 & 5,20761 & .. \\
\hline 2973,19 & 5,14050 & 48,63 \\
\hline 22,8 & 5,09039 & , \\
\hline 30,35 & 4,97169 & .. \\
\hline 227,54 & 4,70294 & 668 \\
\hline 581,54 & 4,62580 & 536,04 \\
\hline 192,53 & 4,60738 & 164,66 \\
\hline 257,67 & 4,45128 & 280 \\
\hline 0,73 & 4,36485 & .. \\
\hline 0,181 & 4,36485 & .. \\
\hline 12,19 & 4,36485 & .. \\
\hline 1025,22 & 4,34973 & 280 \\
\hline 156 & 4,34703 & 32,18 \\
\hline 94,08 & 4,32714 & .. \\
\hline 10,83 & 4,23107 & 130 \\
\hline 18,27 & 4,21724 & .. \\
\hline 325,49 & 4,21461 & 140 \\
\hline 110,62 & 4,16102 & 266,52 \\
\hline 196,85 & 4,13236 & 32,18 \\
\hline 0,96 & 4,09382 & .. \\
\hline 883,59 & 4,02268 & 145 \\
\hline 143 & 4,00193 & .. \\
\hline 10 & 3,99763 & 1470 \\
\hline 23,18 & 3,98714 & 26 \\
\hline 101 & 3,97206 & .. \\
\hline 743,39 & 3,96652 &.. \\
\hline
\end{tabular}




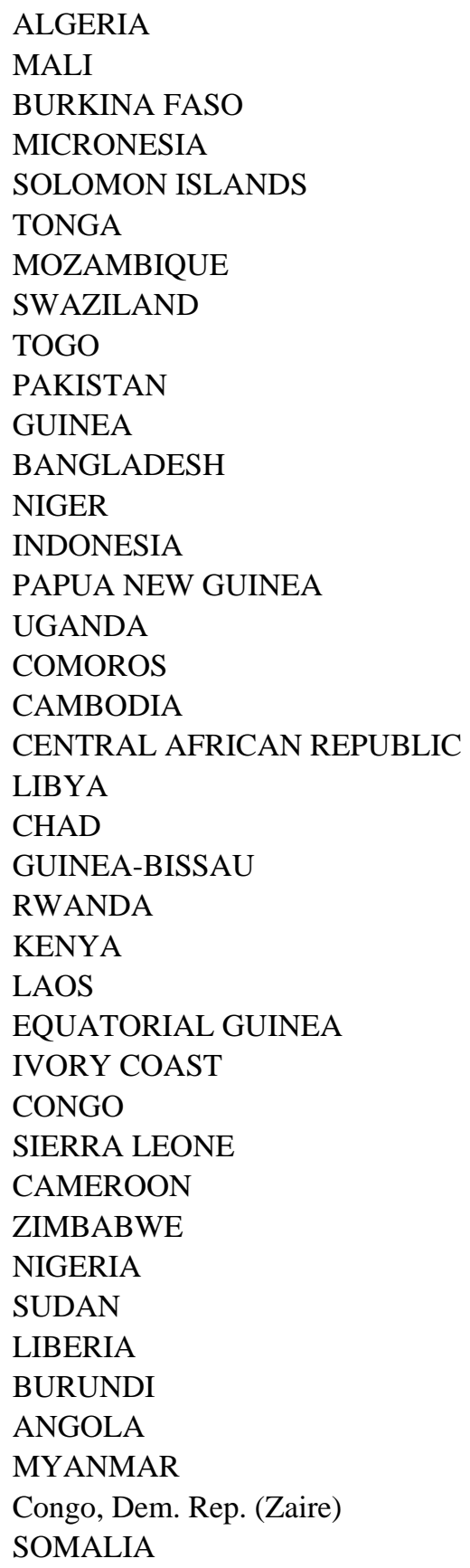

\begin{tabular}{|c|c|c|}
\hline 2381,74 & 3,92323 & 78,2 \\
\hline 1220,19 & 3,92041 & 2940 \\
\hline 273,6 & 3,89737 & 280 \\
\hline 0,702 & 3,71402 & .. \\
\hline 27,99 & 3,71402 & .. \\
\hline 0,72 & 3,71402 & .. \\
\hline 784,09 & 3,69174 & .. \\
\hline 17,2 & 3,66514 & .. \\
\hline 54,39 & 3,65650 & 668 \\
\hline 770,88 & 3,59852 & 36,99 \\
\hline 245,72 & 3,49785 & 483 \\
\hline 130,17 & 3,44713 & 71,41 \\
\hline 1266,70 & 3,43722 & 400 \\
\hline 1811,57 & 3,39629 & 170 \\
\hline 452,86 & 3,36823 & .. \\
\hline 197,1 & 3,32357 & 280 \\
\hline 2,23 & 3,31591 & .. \\
\hline 176,52 & 3,28077 & .. \\
\hline 622,98 & 3,23498 & 280 \\
\hline 1759,54 & 3,17803 & .. \\
\hline 1259,20 & 3,14791 & 280 \\
\hline 28,12 & 2,99980 & 164,66 \\
\hline 24,67 & 2,97910 & 280 \\
\hline 569,14 & 2,91862 & 145 \\
\hline 230,8 & 2,89938 & , \\
\hline 28,05 & 2,61048 & .. \\
\hline 318 & 2,57983 & 668 \\
\hline 341,5 & 2,56587 & 240 \\
\hline 71,62 & 2,50108 & 483 \\
\hline 465,4 & 2,43940 & 280 \\
\hline 386,85 & 2,33349 & .. \\
\hline 910,77 & 2,29163 & 2004 \\
\hline 2376,00 & 2,28822 & 88,2 \\
\hline 96,32 & 2,16352 & .. \\
\hline 25,68 & 2,02717 & 280 \\
\hline 1246,70 & 1,88900 & 280 \\
\hline 657,55 & 1,75994 & 34,6 \\
\hline 2267,05 & 1,41580 & 240 \\
\hline 627,34 & 0,90985 & .. \\
\hline
\end{tabular}

